\title{
DOES GLOBAL FINANCIAL CRISIS INTEGRATE THE REGIONAL MARKET IN ASIA MORE STRONGLY?
}

\author{
ITI VYAS \\ ALOK KUMAR MISHRA \\ School of Economics \\ University of Hyderabad
}

\begin{abstract}
The aim of this paper is to analyze whether the worldwide financial crisis integrates the regional markets in Asia more strongly. Secondly, it is also to examine whether the integration of regional markets in Asia necessarily leads to a weak form of market efficiency. To examine this we have considered the different broad based and liquid stock indices such as the Sensex and BSE 100 from the Bombay Stock Exchange; the S\&P CNX Nifty from the National Stock Exchange, representing India; the Hang Seng Index from the Hong Kong Stock Exchange, representing China; the Kuala Lumpur Composite Index (KLSE), Bursa Malaysia representing Malaysia; the Nikkei 225 from the Tokyo Stock Exchange representing Japan, and the Straits Times Index (STI) from the Singapore Exchange representing Singapore. The study considered the daily data spanning from $4^{\text {th }}$ January 1994 to $2^{\text {nd }}$ May 2012. The full sample period was split into three forms such as the whole sample, the Global financial crisis and the post global financial crisis. The short term interaction was studied by using Toda Yamamoto's procedure of Granger's Causality in VAR Block Exogenity form and the long run equilibrium relationship was tested by applying the Johansen Maximum Likelihood procedure. And so the paper explored the possible, integrating relationship at the volatility level among the regional stock indices by applying the ARCH school of models. Finally, the Random Walk Hypothesis was tested by employing the Chow-Denning (1993) and the Lo and Mackinlay (1988) multiple variance ratio test to examine the efficiency of the market. The major findings of the study indicated that the worldwide financial crisis integrates the regional markets in Asia more strongly in the short term from 2007 onwards. There is no long run equilibrium relationship among the regional stock markets. The study also found that the integration of the financial market does not necessarily contribute to market efficiency.
\end{abstract}

Keywords: Global Financial Crisis, multiple variance ratio, vertical integration, volatility spillovers, market efficiency

JEL Classification: G15, C32

\section{Introduction}

Regional integration is considered a major boost to the global integration process. Apart from Asia's growing integration with the rest of the world, increasing integration within Asia also reflects the growing intraregional trade and financial flows. The South East Asian Crisis of 1997 has turned out to be an opportunity in the pan-Asian region to begin the regional monetary and financial cooperation. Among others, the major initiatives for regional cooperation in Asia includes ASEAN+3, the Chiang Mai Initiative, the Executive's meeting of East Asia-Pacific Central Banks, Asia Bond market initiatives, Asian bond fund, etc. ASEAN has embarked on a process to expand economic cooperation with its neighbors in the north, namely China, Japan and South Korea (ASEAN+3). As far as India's association with ASEAN community is concerned, currently India is not a full-fledged part of the ASEAN network but has a regular 
summit with ASEAN. Furthermore, financial market integration has become significant in the recent period as capital has become more mobile across countries with reduction in capital controls and improvement in technical infrastructure. As a consequence of which, there is an increase in co-movements of interest rates, bond issues and equity indices.

Asia has been emerging as an engine of growth in the world economic system. Financial integration has been prominent along the agenda of the Asian policy-makers over the last decade as a platform for regional development and as a safeguard against the vagaries of the worldwide market (ADB 2008). The integration of the Asian financial markets with the global financial system has been strengthening since 2003 although the degree of integration varies across nations and regions according to the levels of fiscal and economic development. This is because of the fact that Asia received half of the world's net private capital flows to emerging markets in 2003, and two-thirds in 2004. At the same time, the stunning accumulation of official international reserves since 2003 has turned many Asian nations into major holders of advanced economies' sovereign bonds. These facts are powerful evidence of the secretive links between emerging Asian and the worldwide capital marketplace. With regard to the recent global financial crisis, Asian financial markets are relatively less affected because of the implementation of various criteria to safeguard financial system stability following the Asian currency crisis and non-performing asset problems. The prolonging effects of the global financial crisis in the U.S.A. and European financial market open the exit door and entry point to Asian financial markets. Regional and global financial integration will deepen financial markets and beef up the resilience of Asian economies to external shocks. It will also ease the efficient utilization of Asia's huge pool of savings, including investment in the region. This will enable the region to take constituent in the global economy in a more balanced manner. Asian countries have already produced substantial progress in regional financial integration, although local financial market development has progressed more rapidly than regional financial integration.

In the light of the above background, the prominent objective of the paper was to study the impact of the global financial crisis and the post-global financial crisis on the Asian economic integration and in particular in the context of India. The paper also examined whether integration of markets necessarily leads to market efficiency in the context of Asian nations. The major contribution of this theme in the literature is that the paper examines the integration by applying the 'de facto' indicators of financial integration. The methodology was unique in comparison to previous literature in the sense that the paper examined the volatility spillovers across the Asian markets, which was not investigated in previous studies. The paper also differs from previous studies because of its emphasis on only the global and post-global financial crisis period to analyze Asian economic integration. Ultimately, none of the previous studies have tested the theory that market integration does not inevitably contribute to the efficiency of the securities industry, which is tackled in this report.

The rest of this paper is organized as follows. We have highlighted some stylized facts in terms of indicators of trade openness, FDI openness and financial openness in the context of ASEAN economy in section II. The review of empirical literature is specified in the section III. In section IV, we have presented the methodology and description of the variables. The empirical results analyzed in section $\mathrm{V}$ is followed by the conclusion in section VI.

\section{Asian Economic Integration: Some Stylized Facts}

Regional financial integration occurs due to the ties between a given region and the major financial center serving that region. Economic integration is easier to achieve at a regional level due to network externalities and the tendency of market makers to concentrate on certain geographical countries. This section examines the ASEAN economic integration through trade 
openness, financial openness and FDI openness indicators.

Openness to trade refers to the degree to which countries engage in trading activities with other countries or economies. Trade openness is measured by the total trade of a country expressed as a percentage of the nominal GDP in US dollars. A higher value indicates a more open economy. Both developed and developing economies depend more on international trade as openness to trade is used extensively in the economic growth literature as a major determinant of growth performance (Petrakos, Arvanitidis \& Pavleas, 2007). Free trade benefits developing countries because trading with developed countries allows them to exploit the advanced technology and expertise to enhance productivity in their home country, and increases the demand for the domestic goods and services produced. International trade is therefore, an engine of growth (Awokuse, 2007). Export promotion enhances technical changes, and brings economies of scale which in turn reduces inefficiency and increases productivity (Fatima, 2002). Exports increase the level of domestic and foreign competition, improving efficiency resulting in higher productivity, output, and industrialization.

In Figure1, trade openness is measured by the total trade of a country expressed as a percentage of the nominal Gross Domestic Product (GDP) in US dollars. A higher value indicates a more open economy. The figure below reveals that Singapore continued to have more open economy till 2006 and after that China replaced Singapore from 2007 onwards. India had the least open economy from 1990 to 1992 in trade openness. However, in the wake of the New Economic policy initiated in India in 1991, India's trade contribution to GDP increased from 14.54 percent to 37.30 percent in 2010. Japan has the least open economy from 1993 tilltoday.

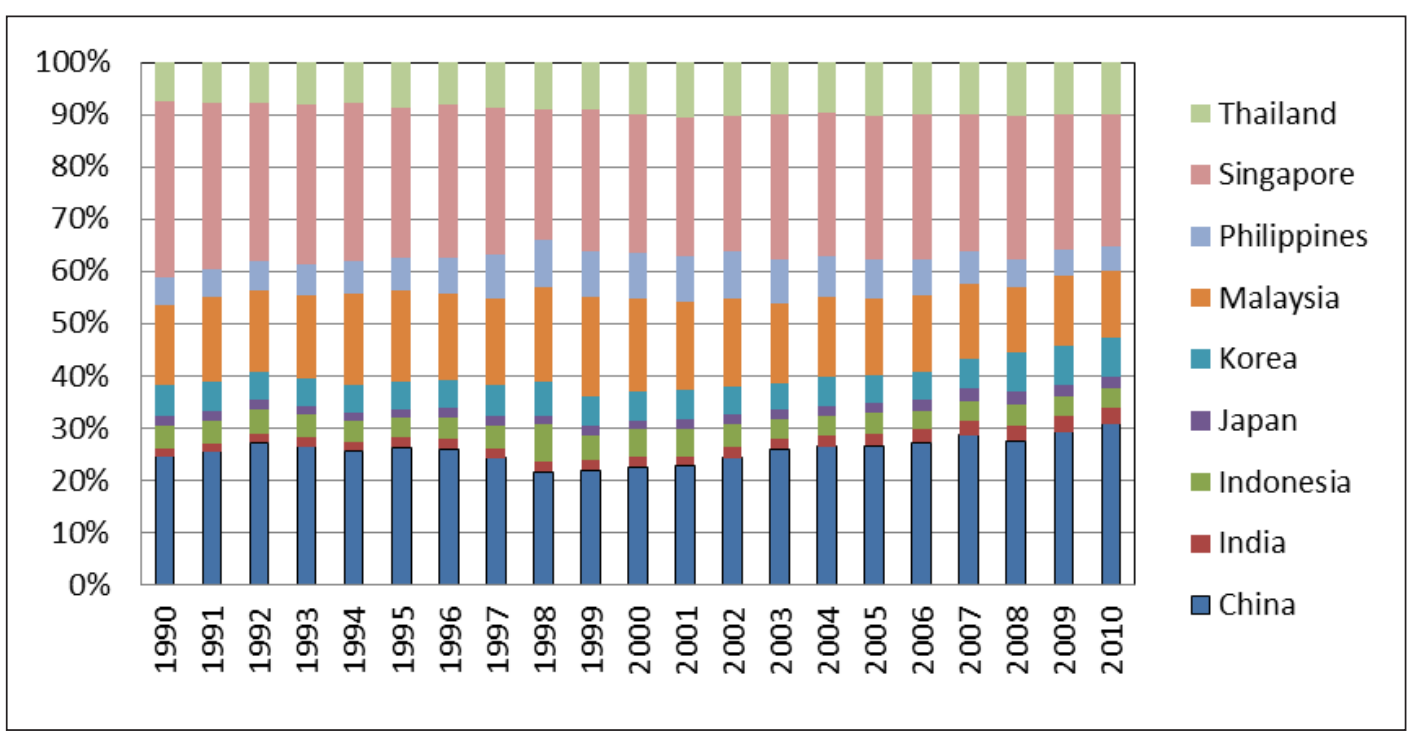

Source: Data compilations from IMF Directions of Trade Statistics, IMF World Economic Outlook Database

Figure 1. Trade openness of Asian countries

Foreign direct investment (FDI) is defined as an investment involving a long-term relationship and reflecting a lasting interest in and control by a resident entity in one economy (foreign direct investor or parent enterprise) of an enterprise resident in a different economy (FDI enterprise or affiliate enterprise or foreign affiliate). Such investment involves both the initial transaction between the two entities and all subsequent transactions between them and among foreign 
affiliates. FDI inflows and outflows comprise capital provided (either directly or through other related enterprises) by a foreign direct investor to a FDI enterprise, or capital received by a foreign direct investor from a FDI enterprise. FDI includes the three following components: equity capital, reinvested earnings and intracompany loans. Data on FDI flows are presented on net bases (capital transactions' credits less debits between direct investors and their foreign affiliates). Net decreases in assets or net increases in liabilities are recorded as credits, while net increases in assets or net decreases in liabilities are recorded as debits. Hence, FDI flows with a negative sign indicating that at least one of the three components of FDI is negative and not offset by positive amounts of the remaining components. These are called reverse investments or disinvestments. The inflow of foreign capital into an economy contributes to an increase in the aggregate investment and overall level of economic activity.

FDI openness is measured by the dollar value of inward FDI stock of a country expressed as a percentage of its nominal GDP in dollars. A higher value indicates a more open economy. The FDI openness of Asian countries from 1990 to 2010 is presented in Figure 2 below. An important observation from Figure 2 surmises that China is continuously dominating as a more open economy among other Asian countries. China's FDI share as a percentage of its nominal GDP was raised from 265.56 percent in 1990 to 489.01 percent in 2010. Next to China, was Singapore, whose economy was more open towards foreign direct investment. FDI openness in the case of Singapore rose from 82.57 percent in 1990 to 210.99 percent in 2010. Japan is the least open economy among the developing Asian countries. FDI openness increased from 0.33 percent in 1990 to 3.94 percent in 2010 in the case of Japan. India followed Japan's FDI openness in the sense that FDI openness in the context of India increased from 0.51 percent in 1990 to 11.49 percent in 2010. This makes a stronger case that India's FDI openness is still in the narrow window in comparision to China and Singapore.

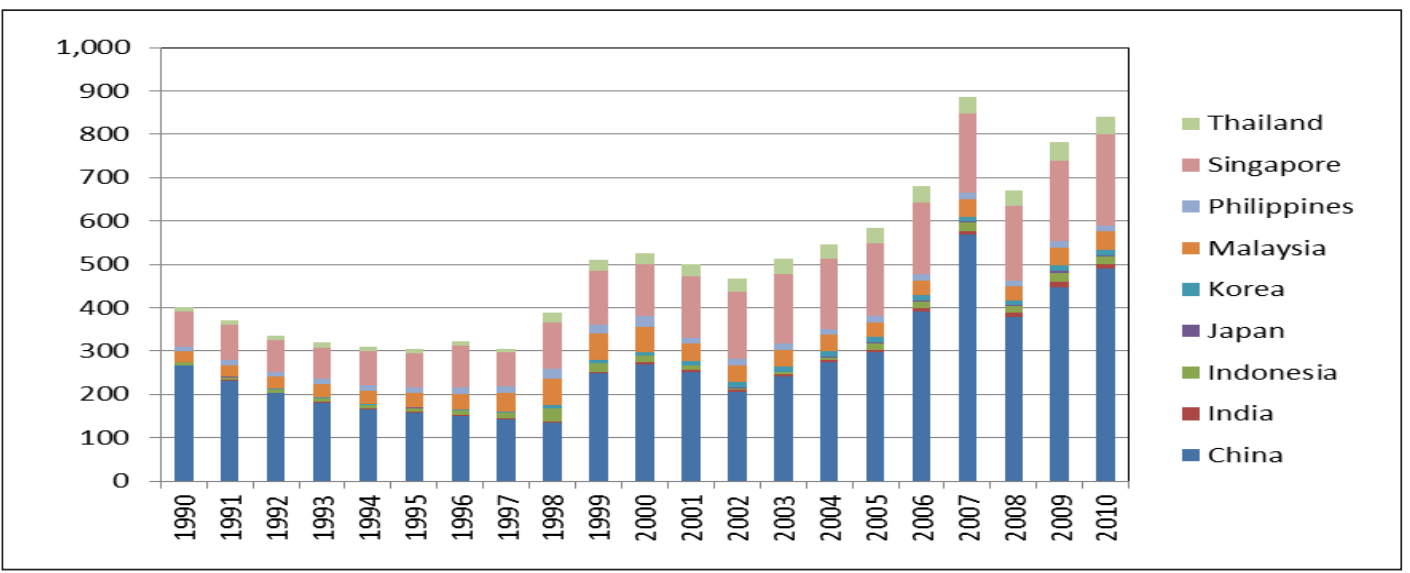

Source: Data compilations from IMF Directions of Trade Statistics, IMF world Economic Outlook Database, UNCTAD

Figure 2. FDI openness of Asian Countries

International debt securities by residence of issuer are the amounts of outstanding debt securities in dollars issued internationally by residents of a country, as reported in the Bank for International Settlements Statistics. It is a measure of the degree of financial openness of a country. A higher amount of financing tapped from the international markets is indicative of greater financial openness. International debt securities outstanding by residence of issuer 
are sourced from the Bank for International Settlements (BIS) Securities Statistics. Data obtained pertain to December of each year. The degree of financial openness is reported in the
Figure 3. This figure reveals that the Japanese economy is a more financial open economy compared to the other Asian countries since 1990 onwards.

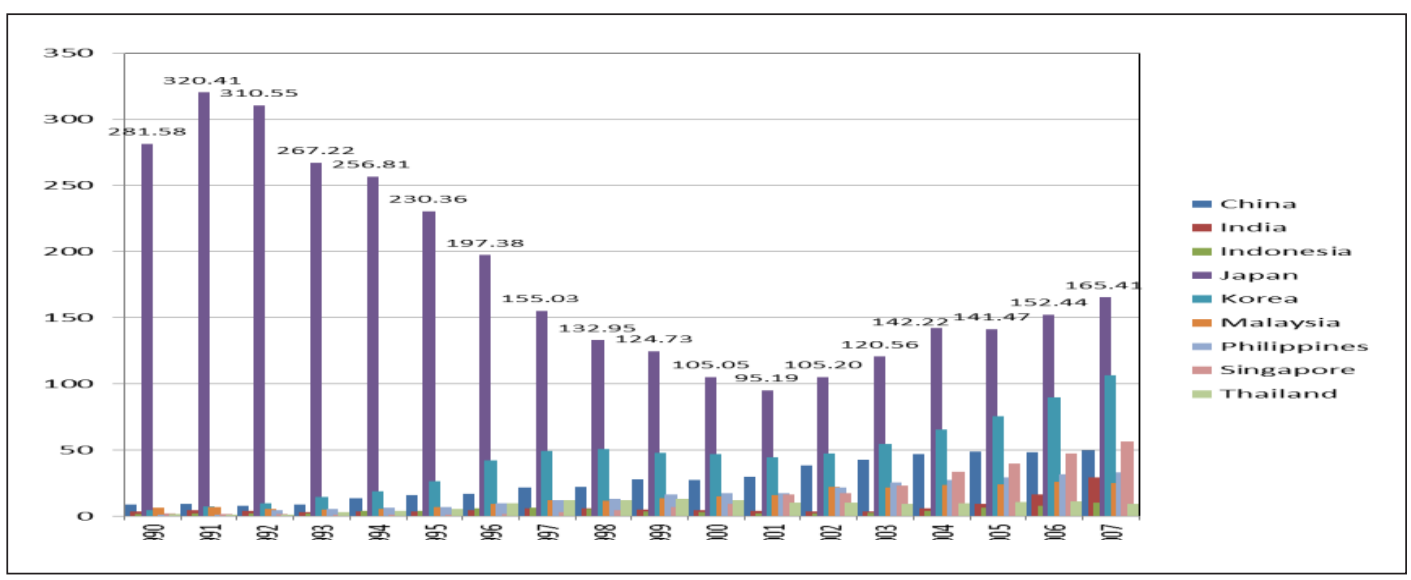

Source: Bank of International Settlement, $A D B$

Figure 3. Money and finance indicators of Asian countries: International debt securities by residence of issuer in billion US \$.

Total trade is the sum of the value of exports and imports. The growth of total trade is the percentage change in the value of total trade relative to the previous year and it is presented in Figure 4. The growth of the total trade growth in percentage was negative for all the Asian countries in the years 1998 and 2009. However, the growth of trade was negative in 2001 for all the Asian countries except India. India achieved the maximum trade growth viz, 35.88 percent in the year 2005 and achieved minimum negative growth $(-10.58 \%)$ in the year 1991 .

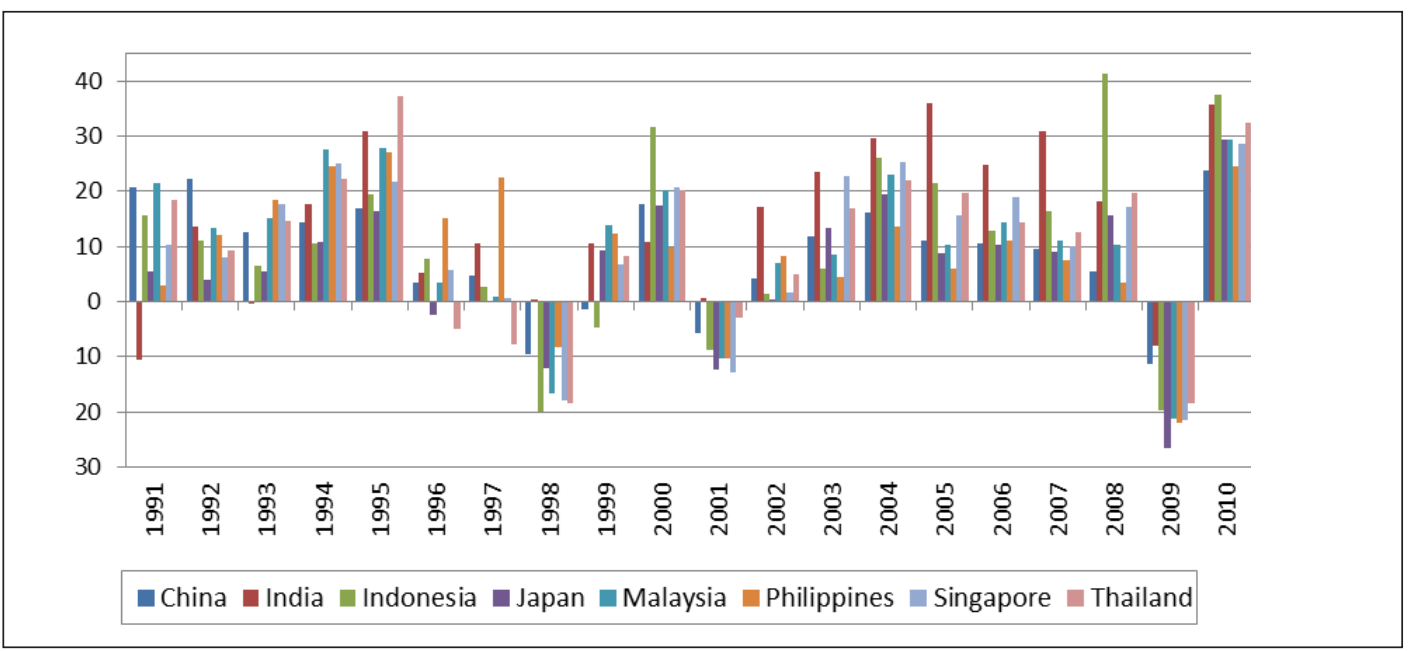

Source: IMF Directions of Trade Statistics

Figure 4. Total trade growth (\%): Asian region 
Thus, by and large, countries in Asia came into the crisis with fairly strong macroeconomic fundamentals, including low inflation and favorable fiscal and current account positions. China, Japan, Korea, and Singapore were among those employing relatively aggressive policy strategies; in particular, China undertook a sizable fiscal program, supplemented by accommodative monetary and bank lending policies. The stimulus packages in China and elsewhere lifted domestic demand throughout the region, boosting intraregional trade (Ben S. Bernanke, 2009).

\section{Empirical Literature Review}

The concept of integration of financial market is a broader issue as the financial system includes the foreign exchange market. The integration of different segments of financial markets is solely based on the movement of the term structure of interest rates, forward premia, credit spreads and the dynamic behavior of asset prices. Financial openness in the post-reform period has created a venue for the interaction of domestic markets and foreign exchange markets. A brief review of these studies is provided below.

Bailey and Stulz (1990) investigated the prospects for international portfolio diversification among Pacific basin stock markets using the daily returns for the Malaysia, Korea, Singapore, Hong Kong, Japan, Philippines, Taiwan and Thailand market indices from January 1977 to December 1985. They used simple correlation analysis to detect interrelations among the markets. Their results showed that the degree of correlation between the US and the Asian equity returns dependended upon the period specification, whether daily, weekly or monthly. For example, with daily returns, only correlations between the US \& Hong Kong, and between Japan \& Taiwan were significant, whereas for monthly returns, correlations between all Asian markets were significant with the exception of the Philippines and Thailand.

Moosa et al. (1997) examined the integration between goods and financial markets in Japan and six Asian countries (Hong Kong, Korea, Malaysia, the Philippines, Singapore and Taiwan). The study considered quarterly data on exchange rates, consumer prices and 3-month Treasury bill rates of Japan and six Asian countries for the period spanning from 1980:1 to 1994:4. By using uncovered interest rate parity and ex-ante purchasing power parity as a direct test for the degree of market integration and the cointegration test they found a high degree of integration among Asian goods and financial markets.

Qiao and Yu (1997) employed the daily stock price indices and spot exchange rates obtained from the financial markets of Hong Kong, Tokyo and Singapore over the period from Jan. 3, 1983 to June 15, 1994 to examine the possible interaction between these financial variables. Based on the Granger causality test, his result found that the changes in stock prices are caused by changes in exchange rates in Tokyo and Hong Kong markets. However, no such causation was found in the Singapore market. On the reverse causality from stock prices to exchange rates, his results show such causation only for the Tokyo market. Therefore, for the Tokyo market, there is a bi-directional causal relationship between stock returns and changes in exchange rates. The study also used the Vector Autoregression model to analyze a long-run stable relationship between stock prices and exchange rates in the above Asian financial markets. His results found a strong, long-run stable relationship between stock prices and exchange rates on levels for all three markets.

Redel (1997) concentrated on capital market integration in developing Asia during the period 1970 to 1994 taking as variables net capital flows, FDI, portfolio equity flow and bond flows. He observed that capital market integration in Asian developing countries in the 1990's was a consequence of broad-based economic reforms, especially in the trade and financial sectors. He concluded that deepening and strengthening the process of economic liberalization in the Asian developing countries is essential for minimizing the risks and maximizing the benefits of increased international capital market integration. 
Studying the long-run and short-run dynamics between stock prices and exchange rates on six Pacific basin countries such as Hong Kong, Indonesia, Malaysia, Singapore, Thailand and the Philippines over the period 1980 to 1998 through co integration and the multivariate Granger causality tests, Katephylaktis and Fahiala Ravazzolo (2000) concluded that: (a) there was no long-run relationship between the real exchange rate and the local stock market in each Pacific basin countries during the 1980s or 1990s except Hong Kong, (b) for all the countries the real exchange rate and the US stock prices were positively related to domestic stock prices in the 1990s, (c) foreign exchange restrictions were not found to be important determinants of the link between the domestic stock and foreign exchange markets on the one hand and between domestic capital and world capital markets on the other hand.

Amare and Mohsin (2000) examined the long-run association between stock prices and exchange rates in Japan, Hong Kong, Taiwan, Singapore, Thailand, Malaysia, Korea, Indonesia and the Philippines. The study considered monthly data spanning from January 1980 to June 1998 and employed the Cointegration technique. The long-run relationship between stock prices and exchange rates was found only in Singapore and the Philippines. They attributed this lack of cointegration between the said variables to the bias created by the "omission of important variables". When an interest rate variable was included in their cointegrating equation, they found cointegration between stock prices, exchange rates and interest rates for six of the nine countries.

Bala Ramasamy and Matthew Yeung (2001) studied the hit - and - run behavior in the interaction between stock prices and exchange rates of nine countries hit by the Asian flu such as Hong Kong, Indonesia, Japan, South Korea, Malaysia, the Philippines, Singapore, Thailand and Taiwan. The study considered the quarterly data spanning from $1^{\text {st }}$ January 1997 to $31^{\text {st }}$ December 2000, forming around 1040 samples for each country. By employing the Granger causality test, the study concluded that stock prices Granger cause movements in the exchange rate in case of all the countries except Hong Kong. Hong Kong showed bicausality. Bala Ramasamy and Matthew C.H.Yeung (2002) examined the links between foreign exchange and stock markets in six countries in the East Asia region such as Indonesia, South Korea, Malaysia, Thailand, the Philippines and Singapore. The study considered the period from $2^{\text {nd }}$ January 1995 to $6^{\text {th }}$ August 2001, forming around 1,720 observations. By employing the cointegration test and Granger causality test, the study concluded that there were inconsistent results in tests for bivariate causality between stock prices and exchange rates. This finding suggested that the stock and foreign exchange markets in the region might still be unstable. Worthington A.C et al. (2004) examined price linkages among Asian equity markets in the period surrounding the recent Asian economic, financial, and currency crises. The data employed in the study was composed of valueweighted equity market indices for nine Asian markets viz. Hong Kong, Japan and Singapore (developed markets), and six emerging markets, Indonesia, Korea, Malaysia, the Philippines, Taiwan and Thailand for the period spanning from $1^{\text {st }}$ January 1988 to $18^{\text {th }}$ February 2000 . By applying multivariate cointegration and VAR procedures they found that there was a stationary relationship and significant causal linkages between the Asian equity markets. On the other hand, causal relationships that exist between the developed and emerging markets suggest that opportunities for international portfolio diversification in the Asian equity market still exist.

The above literature review vindicates the fact that most of the previous literature has unleashed integration among the markets by employing comovement analysis, causality analysis and cointegration analysis. Nevertheless, the outcome is sensitive towards the frequency of the data and the sample size. One group of studies support the consolidation among the markets 
and at the same time the other group of studies concludes that there is no integration at all. Hence the determination is mixed and inconclusive. Most of the studies analyzed integration at the price level, but we analyzed integration among the Asian markets both at the price as well as the volatility level. Unlike, previous studies, the present study have undertook market efficiency and volatility spillovers among the markets to examine integration and efficiency among the markets.. This issue is brought up in the following segment.

\section{Empirical Methodology and Data}

With a view to examine the integration of the Indian stock market with the regional stock markets, we have considered the different broad-based and liquid stock indices such as the Sensex and BSE 100 from the Bombay Stock Exchange, the S\&P CNX Nifty from the National Stock Exchange representing India, the Hang Seng Index from the Hong Kong Stock Exchange representing China, the Kuala Lumpur Composite Index (KLSE), Bursa Malaysia representing Malyasia, Nikkei 225 from the Tokyo Stock Exchange representing Japan, the Straits Times Index (STI) from the Singapore Exchange representing Singapore. The daily closing prices of these respective indices were collected from their respective official websites, and the website of the Asian Regional Centre, yahoo finance and google finance.

The study considered the daily data spanning from $4^{\text {th }}$ January 1994 to $2^{\text {nd }}$ May 2012 which was around 3908 observations. The entire sample period was divided into three phases such as the whole sample, the Global financial crisis and the post-global financial crisis. The global financial crisis spanned from 2007 to 2008, which was around 429 observations and the post-global financial crisis phase spanned from 2009 to 2012, which around 715 observations.

A variety of econometric methods were used in the study to carry out the empirical analysis. At the outset, we employed the Toda and Yamamoto (2005) Granger's Non-causality test in the VAR
Block Exogeneity form, the Johansen Juselius multi-variable co-integration (1988) test, and the Vector Auto Regression (VAR) model to examine the short-term and long-term dynamic interactions between the Indian financial markets and the global financial markets. As the above empirical analysis necessitates checking for the possible unit roots in the data, the Augmented Dickey Fuller test (ADF) and the Phillips-Perron (PP) test were employed to make them stationary and to find out their order of integration. The study also used conditional heteroscedastic models such as the Auto regressive conditionally Heteroscedastic model (ARCH), the generalized $(\mathrm{ARCH})$ model, Exponential (GARCH) model to trace out the volatility spillover between the Indian financial markets and the global financial markets. As these methods are celebrated time series tools and are available in any standard time series econometric textbook, we are not explaining these here.

To examine the volatility spillovers between the above mentioned financial markets, the same was carried over in two ways. First, the volatility series was generated from the specific model and was extracted for each of the individual financial market segment return. Then in order to ascertain the possible existence of co-movement among them, we applied the Johansen Jussillieus (1988) cointegration test. Second, the residuals were generated from a specific model and for a particular market. These residuals were used as shocks emanating in one market and are made to enter into the volatility equation of the other market. If the coefficient was significant, it confirms the presence of volatility spillover.

The AR (1) equation as well as both the GARCH $(1,1)$ and $\operatorname{EGARCH}(1,1)$ spillover equations may be defined as follows:

$$
\operatorname{AR}(1): y_{t}=c+\tau y_{t-1}+\varepsilon_{t} \ldots
$$

where, $y_{t}$ is the return of the stock indices at time period $t$; $c$ is the intercept; $y_{t-1}$ is the previous period return at the time period $t-1$ and $e_{t}$ is the white noise error term. Here, the return on the daily stock prices are a function of the previous period returns of stock indices plus an error term. 


\section{GARCH (1,1) Spillover Equation}

$$
\begin{aligned}
& h_{t(\text { Domestic Stock Indices })}=\omega_{0}+\beta_{1} \varepsilon_{t-1}^{2}+\alpha_{1} h_{t-1}+\psi\left(\text { sqresid }_{\text {RegionalStock Indices }}\right) \\
& h_{t(\text { RegionalStock Indices })}=\omega_{0}+\beta_{1} \varepsilon_{t-1}^{2}+\alpha_{1} h_{t-1}+\psi\left(\text { sqresid }_{\text {Domestic Stock Indices }}\right)
\end{aligned}
$$

where, $\omega_{0}>0, \beta_{1} \geq{ }^{3} 0, \alpha_{1} \geq{ }^{3} 0$. In both equations (2) and ( 3$), h_{t}$ is the conditional variance of both stock indices respectively, which is a function of mean $\omega_{0}$ news about volatility from the previous period is measured as the lag of the squared residual from the mean equation $\left(\varepsilon_{\mathrm{t}-1}{ }^{2}\right)$, the last period's forecast variance $\left(\mathrm{h}_{\mathrm{t}-1}\right)$ and the squared residual of stock indices respectively in both the above equations. In a similar way we examined the volatility spillovers between the domestic and global stock indices.

In the GARCH $(1,1)$ spillover equation, we used the squared residual of another market (y) instead of the residual on their level, which was used, as a proxy for shock in the other market because in the case of GARCH, we made sure that volatility was positive.

\section{EGARCH (1,1) Spillover Equation}

$$
\begin{aligned}
& \ln h_{t(\text { Domestic Stock Indices })}=\omega_{0}+\beta_{1} \ln h_{t-1}+\alpha_{1}\left|\frac{\varepsilon_{t-1}}{\sqrt{h_{t-1}}}\right|+\phi \frac{\varepsilon_{t-1}}{\sqrt{h_{t-1}}}+\psi\left(\text { resid }_{\text {Re gionalStock Indices }}\right) \\
& \ln h_{t(\text { Re gionalStock Indices })}=\omega_{0}+\beta_{1} \ln h_{t-1}+\alpha_{1}\left|\frac{\varepsilon_{t-1}}{\sqrt{h_{t-1}}}\right|+\phi \frac{\varepsilon_{t-1}}{\sqrt{h_{t-1}}}+\psi\left(\text { resid }_{\text {Domestic Stock Indices }}\right)
\end{aligned}
$$

The above equation represents the EGARCH $(1,1)$ model. these equations, $\ln \mathrm{h}_{\mathrm{t}}$ is the natural logarthimic of variance, which automatically restricts the volatility to be positive; $\mathrm{w}_{0}$ is the constant level of volatility; $\beta_{1} \ln h_{t-1}$ explains the consistence as this is a function of past volatility. The coefficient $a_{1}$ measures the reaction of volatility to change in the news. It is important to remark here that, we took the residual modulus which measures the relation with respect to positive news. The coefficient $\mathrm{f}_{1}$ explains the relationship of volatility to both positive and negative news as we did not take the modulus. The coefficient y represents the volatility spillovers coefficient. In Equation 4, residuals are generated from the EGARCH model of global stock indices, whereas in Equation 5, residuals are generated from the EGARCH model of domestic stock indices. In the above EGARCH $(1,1)$ model, only residuals of other markets were taken into consideration instead of squared residual, since EGARCH, by definition ensures that volatility is positive.

Finally to study financial market efficiency, the study examined the Variance Ratio tests of the Random Walk hypothesis. The study employed the Lo and Mackinlay (1988), Chow and Denning (1993) methods of Variance Ratio test to analyze the weak form of efficiency of all the global stock markets.

\section{Empirical Analysis}

To start with, before undertaking any time series econometric analysis of the data, it would be useful to examine the broad trends and behavior 
of the variables, which may help in interpreting the model results latter. For this purpose, time series plots were drawn for all the concerned variables. Figure 5 presents the co-movements of India's stock market with those of the regional stock markets. The financial integration process can be visualized in three phases: (a) the period from the 1994 s to the 1998s, which was associated with various crises in emerging market economies, including the Asian crisis in 1997-98, (b) the postcrisis period since 2003, which was characterized by the revival of private foreign capital flows to emerging market economies in an environment of liberalization, flexible exchange rates and strong economic growth and (c) in the post-global financial crisis period, when the co-movements of the stock indices reflected more co-integration with each other. However, in this study, we focused our analysis only on the global financial crisis and post global-financial crisis along with the whole sample to examine the degree of financial market integration and their efficiency.

The correlation among pairwise stock market returns is a measure of co-movement analysis among the stock markets. A higher correlation indicates a higher degree of integration in the markets. The correlation matrix at the return level has generated for the concerned stock indices. However, the values of correlation

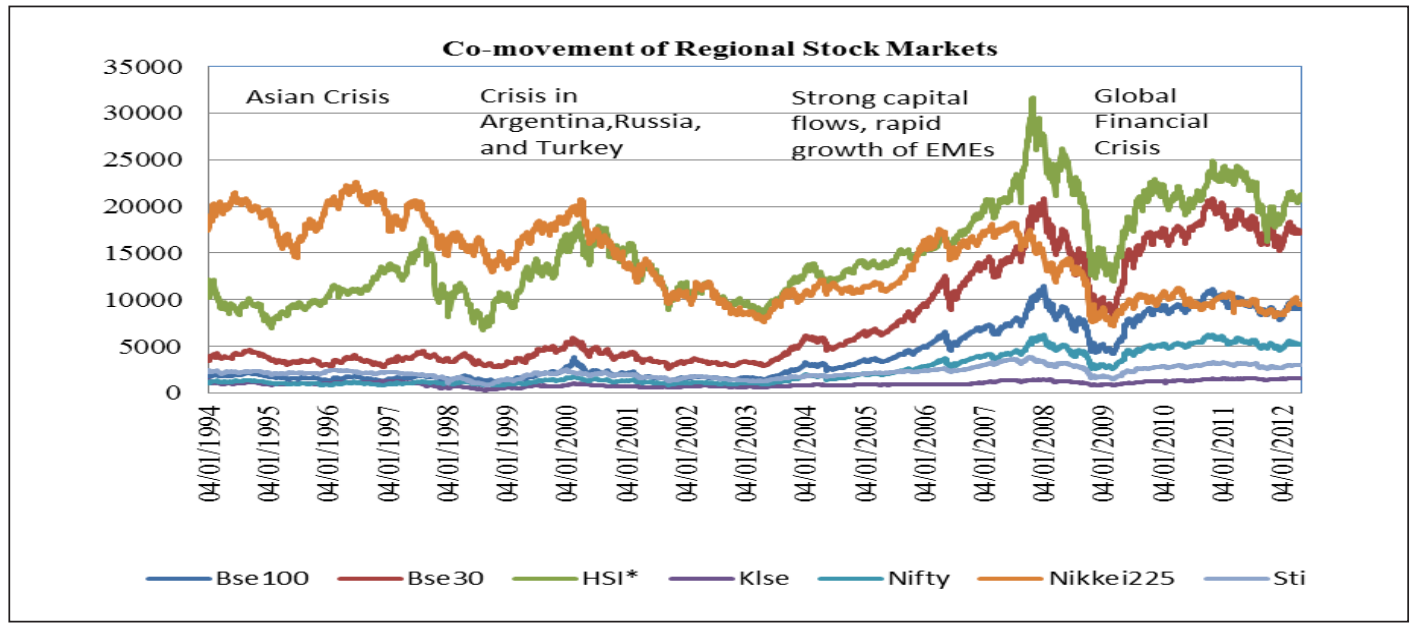

Source: Author's Compilation

Figure 5. Time series plot of regional stock indices

coefficients along with their corresponding statistical significance level are only reported for the phase of global financial crisis in Table 1 because of the lack of the space. At the return level, a higher pairwise positive correlation among all the stock indices at a conventional confidence level during the global financial crisis and post- global financial crisis period.

Table 1

Correlation of Stock Market Returns: Phase II: 2007-2008: Global Financial Crisis

\begin{tabular}{llcccccc}
\hline & $\begin{array}{c}\text { BSE30 } \\
\text { RET }\end{array}$ & $\begin{array}{c}\text { BSE100 } \\
\text { RET }\end{array}$ & $\begin{array}{c}\text { NIFTY } \\
\text { RET }\end{array}$ & HISRET & KLSERET & $\begin{array}{c}\text { NIKKEI225 } \\
\text { RET }\end{array}$ & STIRET \\
\hline BSE30 RET & 1 & & & & & & \\
BSE100 RET & 0.99 & & & & & & \\
& $(0.00)$ & & & & & & \\
\hline
\end{tabular}




\begin{tabular}{lcrrrrrr}
\hline & $\begin{array}{c}\text { BSE30 } \\
\text { RET }\end{array}$ & $\begin{array}{c}\text { BSE100 } \\
\text { RET }\end{array}$ & \multicolumn{1}{c}{$\begin{array}{c}\text { NIFTY } \\
\text { RET }\end{array}$} & HISRET & KLSERET & $\begin{array}{c}\text { NIKKEI225 } \\
\text { RET }\end{array}$ & STIRET \\
\hline NIFTY RET & 0.99 & 0.99 & 1 & & & & \\
& $(0.00)$ & $(0.00)$ & & & & & \\
HSIRET & 0.72 & 0.72 & 0.72 & 1 & & & \\
& $(0.00)$ & $(0.00)$ & $(0.00)$ & & & & \\
KLSE RET & 0.55 & 0.56 & 0.55 & 0.62 & 1 & & \\
& $(0.00)$ & $(0.00)$ & $(0.00)$ & $(0.00)$ & & & \\
NIKKEI225 & 0.58 & 0.58 & 0.57 & 0.74 & 0.58 & & \\
RET & $(0.00)$ & $(0.00)$ & $(0.00)$ & $(0.00)$ & $(0.00)$ & & \\
& 0.72 & 0.71 & 0.72 & 0.86 & 0.67 & 0.74 & \\
STIRET & $(0.00)$ & $(0.00)$ & $(0.00)$ & $(0.00)$ & $(0.00)$ & $(0.00)$ & \\
& & & & & & & \\
\hline
\end{tabular}

Source: Author's Computation,

Note: Figures in the parentheses ( ) represents 'p' values

The summary of the statistical moments of stock indices at their respective return levels of all the three phases were computed. However, we have presented only the results of the whole sample and the global financial crisis phase because of the lack of the space here. The stock indices have a very small positive rate of returns (in case of the whole sample and the negative returns in the phase of global financial crisis) per day and the kurtosis coefficient, a measure of the thickness of the tail of the distribution, is quite high. A Gaussian (normal) distribution has a kurtosis equal to three, and hence, this implies that the assumption of Gaussianity cannot be made for the distribution of the concerned variables at their respective returns in all the phases. However, the stock indices at their return levels follow the platykurtic distribution, a fatter short tail in all the phases. This finding is further strengthened by the Jarque Bera test for normality, and this rejects the null hypothesis of normality of return distributions, and thus rejects the null hypothesis of the normality at any conventional confidence level.

Table 2

Statistical Moments of Stock Returns

\begin{tabular}{lccccccc}
\hline \multicolumn{7}{c}{ Phase I: Whole Sample: 4th Jan 1994 to 2nd May 2012 } \\
\hline Statistics & Bse30Ret & Bse100Ret & NiftyRet & HsiRet & KlseRet & Nikkei225Ret & StiRet \\
Mean & 0.0004 & 0.0004 & 0.0004 & 0.0001 & 0.0000 & -0.0002 & 0.0001 \\
Median & 0.0008 & 0.0010 & 0.0007 & 0.0003 & 0.0002 & 0.0001 & 0.0001 \\
Maximum & 0.1599 & 0.1549 & 0.1633 & 0.1680 & 0.2276 & 0.1323 & 0.2147 \\
Minimum & -0.1921 & -0.2200 & -0.2200 & -0.1597 & -0.2415 & -0.1211 & -0.0922 \\
Std. Dev. & 0.0183 & 0.0185 & 0.0182 & 0.0186 & 0.0165 & 0.0162 & 0.0151 \\
Skewness & -0.1585 & -0.4068 & -0.3535 & 0.2306 & 0.5050 & -0.2386 & 0.8573 \\
Kurtosis & 10.8442 & 13.0449 & 13.7951 & 11.4098 & 48.1339 & 8.9046 & 19.4283 \\
Jarque-Bera & $1.00 \mathrm{E}+04$ & $1.65 \mathrm{E}+04$ & $1.91 \mathrm{E}+04$ & $1.15 \mathrm{E}+04$ & $3.32 \mathrm{E}+05$ & $5.71 \mathrm{E}+03$ & $4.44 \mathrm{E}+04$ \\
Probability & 0.0000 & 0.0000 & 0.0000 & 0.0000 & 0.0000 & 0.0000 & 0.0000 \\
\hline \multicolumn{7}{c}{} \\
\end{tabular}




\begin{tabular}{lccccccc}
\hline \multicolumn{7}{c}{ Phase V: 2007-2008: Global financial crisis } \\
\hline Mean & -0.0008 & -0.0008 & -0.0007 & -0.0008 & -0.0005 & -0.0016 & -0.0012 \\
Median & 0.0009 & 0.0014 & 0.0006 & 0.0004 & 0.0001 & -0.0003 & -0.0006 \\
Maximum & 0.0869 & 0.0855 & 0.0852 & 0.1289 & 0.0475 & 0.1323 & 0.0935 \\
Minimum & -0.1921 & -0.2200 & -0.2200 & -0.1597 & -0.0998 & -0.1211 & -0.0922 \\
Std. Dev. & 0.0262 & 0.0266 & 0.0264 & 0.0255 & & 0.0233 & 0.0196 \\
Skewness & -0.9815 & -1.4779 & -1.5405 & -0.1567 & -0.5914 & -0.1365 \\
\hline & & \multicolumn{7}{c}{ Phase V: $2007-2008:$ Global financial crisis } & & 7.4802 \\
\hline Kurtosis & 10.5929 & 14.5368 & 15.1556 & 9.4625 & & 10.4344 & $1.01 \mathrm{E}+03$ \\
Jarque-Bera & $1.10 \mathrm{E}+03$ & $2.54 \mathrm{E}+03$ & $2.81 \mathrm{E}+03$ & $7.48 \mathrm{E}+02$ & & 360.1177 \\
Probability & 0.0000 & 0.0000 & 0.0000 & 0.0000 & & 0.0000 & 0.0000 \\
\hline
\end{tabular}

Source: Author's computation

Taking into account the non-stationary nature of most of the time series data, we employed the Unit Root tests. The use of the co-integration test necessitates the pretest of the presence of Unit Root in the data. The Unit Root tests, namely ADF and PP (both with and without trend and intercept) are conducted to check the stationarity property of the data as well as to check the order of integration. The results of the concerned variables are provided in Table 3. The results show that the null hypothesis of the unit root cannot be rejected even at the 10 percent level of all the concerned stock indices at their levels. However, the null hypothesis of unit root is rejected for all the variables at their return level, and, hence, it can be concluded that they are integrated in order 1, that is I (1) and all the stock indices at their return levels are stationary.

Table 3

\section{Unit Root Test}

\begin{tabular}{lcccc}
\hline \multirow{2}{*}{ Variable } & \multicolumn{3}{c}{ Variables at level } \\
\cline { 2 - 4 } \multicolumn{1}{c}{ With Trend and Intercept } & \multicolumn{2}{c}{ Without Trend and Intercept } \\
\hline BSE30 & ADF & PP & ADF \\
BSE100 & $-2.10(4)$ & $-2.10(9)$ & $0.84(4)$ & $0.81(9)$ \\
NIFTY & $-2.19(4)$ & $-2.21(9)$ & $0.78(4)$ & $0.74(9)$ \\
HSI & $-2.23(4)$ & $-2.22(9)$ & $0.84(4)$ & $0.82(9)$ \\
KLSE & $-2.79(4)$ & $-2.89(9)$ & $0.07(4)$ & $0.02(9)$ \\
NIKKEI225 & $-2.02(4)$ & $-2.29(9)$ & $0.18(4)$ & $0.02(9)$ \\
STI & $-2.23(4)$ & $-2.29(9)$ & $-1.11(4)$ & $-1.01(9)$ \\
\hline
\end{tabular}

\begin{tabular}{lcccc}
\hline & \multicolumn{2}{c}{ Variables at Return Level (Natural Logarithmic of First Difference of spot prices) } \\
\hline \multicolumn{1}{c}{ Variables } & \multicolumn{2}{c}{ With trend and intercept } & \multicolumn{2}{c}{ Without trend and intercept } \\
Bse30Ret & ADF & PP & ADF & PP \\
Bse100Ret & $-27.86(4)$ & $-60.57(9)$ & $-27.82(4)$ & $-60.55(9)$ \\
& $-26.88(4)$ & $-59.25(9)$ & $-26.82(4)$ & $-59.24(9)$ \\
\hline
\end{tabular}




\begin{tabular}{lcccc}
\hline & \multicolumn{2}{c}{ Variables at Return Level (Natural Logarithmic of First Difference of spot prices) } \\
\hline \multirow{2}{*}{ Variables } & \multicolumn{2}{c}{ With trend and intercept } & \multicolumn{2}{c}{ Without trend and intercept } \\
KlseRet & ADF & PP & ADF & PP \\
Nikkei225Ret & $-27.38(4)$ & $-62.98(9)$ & $-27.35(4)$ & $-62.96(9)$ \\
StiRet & $-29.51(4)$ & $-64.75(9)$ & $-29.51(4)$ & $-64.76(9)$ \\
\hline
\end{tabular}

Note: The Mackinnon critical values with trend and intercept at 1\%,5\% and $10 \%$ levels are $-3.96,-3.41$ and -3.12 respectively and the critical values without trend and intercept at $1 \%, 5 \%$ and $10 \%$ level are -2.56 , -1.93 , and -1.61 respectively.

In order to examine the short-run dynamic interaction between the regional stock indices in all the six phases, we employed the Toda and Yamamoto's procedure of Granger's causality test in the VAR Block Exogeneity form. This test requires the optimum lag length to run the Wald test on the regional stock indices. A few previous researches have employed 5-days lag because of 5 days of the trading in a week for the stock market, whereas some studies employed the Akaike's information criterion (AIC $(1969,1970)$ ) and the Final Prediction Error (FPE) criterion to search for the optimum lag length that produces the causality, though in the financial world, where information flow is near perfect, the time lag would be fairly short as investors react almost immediately to information in the market. We employed the Log Likelihood, Likelihood Ratio test (LR), Akaike's information criterion (AIC), Final Prediction Error (FPE), Schwarz Information Criterion (SIC), and Hannan Quinn Criterion (HQ), to choose the optimal lag length. These lag specification criteria result in all the three phases are reported in Table 4 in the appendix. In practice, it may not be possible that all the criteria will suggest one lag length as optimal. In this paper, the optimum lag length is considered, which is unanimously supported by two to three criteria only. The optimum lag length is marked with an asterisk (*) in each of the phases.

The pairwise Granger Causality test among the regional stock indices returns for all the three phases are reported in Tables 5 to 7 in the appendix. At the regional level, the Toda and Yamamoto Granger's Non-causality test results for daily closing returns show that there exists a bidirectional causality between Sensex and BSE 30, Sensex and Nifty, Sensex and Kuala Lumpur Composite Index (KLSE), Sensex and Nikkei 225, Nifty and KLSE, Nifty and Nikkei 225 and Hang Seng Index (HSI) and Straits Times Index (STI). However, there exists a unidirectional causality between BSE 100 and KLSE, BSE 100 and Nikkei 225, KLSE and HSI, KLSE and Nikkei 225 and Nikkei 225 and STI at the whole sample level. However, during the global financial crisis phase, there exists both bidirectional and unidirectional causality among all the concerned pairs except between Sensex and Nifty, BSE 100 and Nifty, BSE 100 and HSI, HSI and Nifty, HSI and Nikkei 225, KLSE and Sensex, KLSE and BSE 100, KLSE and Nifty, KLSE and HSI, Nikkei 225 and Nifty, Nikkei 225 and HSI, STI and Nifty, STI and HSI, STI and Nikkei 225. In the post-global financial crisis phase, there exists both unidirectional and bidirectional causality between all the pairs except between Sensex and BSE 100, HSI and Sensex, HSI and Nifty, KLSE and Sensex, KLSE and BSE 100, KLSE and Nifty, KLSE and Nikkei225, KLSE and STI, Nikkei 225 and Sensex, Nillei 225 and BSE 100, Nillei 225 and Nifty, Nillei 225 and HSI, Nillei 225 and STI, STI and Sensex, and STI and Nifty.

Hence, in toto, there exists consistent short-term causality between the regional stock markets during the global financial crisis and the postglobal financial crisis periods in comparison to the whole sample. Therefore, it can be surmised that the global financial crisis integrated the regional markets in Asia more strongly in the short-term from 2007 onwards. 
After examining the short-term dynamic interaction among the pairs of regional stock indices, we proceeded towards the co-integration test in order to examine the long-run equilibrium relationship among the stock indices by employing the Johansen Maximum Likelihood procedure. The results of the co-integration test for all the phases reported in Tables 8 to 10 .

Table 8 summarizes the co-integration results of the closing prices of the regional stock indices at the whole sample level. The test of trace statistics shows that, the null hypothesis of the variables is not co-integrated $(\mathrm{r}=0)$ against the alternative hypothesis of one or more co-integrating vectors $(r>0)$. Since 130.77 is greater than $5 \%$ but less than $1 \%$ critical value of $1_{\text {trace }}$ statistic (in the first panel of Table 8), we failed to reject the null hypothesis of the no co-integrating vectors. Next, we used the $1_{\text {max }}$ statistics, the null hypothesis of the no co-integrating vectors $(r=0)$ against the specific alternative $(r=1)$ that cannot be rejected. The calculated value $1_{\text {max }}(0,1)=46.34$ is greater than $5 \%$ but less than $1 \%$ critical value. Hence, the null hypothesis cannot be rejected at the $1 \%$ level. Therefore, it can be concluded that there is no co-integrating vector in the whole sample period and also there is no existence of the longrun equilibrium relationship among the regional stock indices.

In a similar fashion, we analyzed the cointegration results for the global financial crisis and the post global financial crisis phases in order to find out the existence of the long-run equilibrium relationship between the pair of regional stock indices. However, surprisingly, the co-integration result confirmed that there is no long run equilibrium relationship between the regional stock markets during any of the periods studied.

In the next phase, we examined the volatility spillovers between the Indian Stock Market and the regional stock markets in the conditional volatility framework. To start with, the study fitted the Auto Regressive Moving Average (ARMA) model of different orders. This carried out primarily to eliminate the first degree auto correlation among the returns, which makes the data amenable for further analysis. This also vindicates the fact that residuals from a fitted model of stock returns exhibit no autocorrelation whereas squared residuals are associated with significant correlations among themselves over time. In fact, this makes the case for applying the ARCH class of models, which are based on this notion. In tune with this, we presented the results due to the fitted ARMA model to the respective return series in Table 11 which shows that the ARMA coefficients for all the stock indices returns are highly significant. After fitting the ARMA model with different orders, we tested for the presence of autocorrelation among the residuals as well as the squared residuals from the fitted model. The results from Ljung Box Q statistics, which were used to test the null hypothesis of 'No Autocorrelation' against the alternative existence of autocorrelation, are reported in Table 11. From the results, it is inferred that the null hypothesis is not rejected in the case of residuals whereas it is strongly rejected in the case of squared residuals. Prima facie, this creates the case to apply the GARCH models. In order to confirm the presence of the ARCH effect in the data, we went for the LaGrange Multiplier (LM) Test and the result shows that the null hypothesis of 'No ARCH Effect' is strongly rejected in the case of all the concerned variables.

The study used both the GARCH and EGARCH models to test for volatility spillover and the same was carried over in two ways. First, the volatility series generated from the specific model entertained were extracted for both the Indian stocks the returns as well as return in the Regional stock markets. Then in order to ascertain the possible existence of co-movement among them, the Johansen Maximum Likelihood Co-integration test was applied. We also tested volatility spillover in a different way. First, the residuals were generated from a specific model and for a particular market. These residuals were used as shocks emanating in one market and were made to enter into the volatility equation of the other markets. If the coefficients are found to be significant, this confirms the presence of volatility spillover. The result of the Volatility spillovers is presented in Tables 12 to 14 . 
However, it is needless to mention over here that we presented the volatility spillover result of the Sensex and HSI returns due to lack of space in this paper.

At the outset in Table 12, the estimation results of AR (1)-GARCH $(1,1)$ as well as that of AR (1)-EGARCH $(1,1)$ model have been provided in the context of Sensex (BSE 30) Ret and HSI Ret. It may be pointed out that the study used the GARCH and EGARCH models of order $(1,1)$ because this order has been found to provide the most parsimonious representation of the ARCH class of models and at the same time empirically the acceptability of the order has been strongly proved. Apart from this, we discussed the basis on which we selected the EGARCH model as it incorporates the sign of the residuals in the volatility equation and thus distinguishes between bad news and good news. The results presented in Table 12 show that all the coefficients of the GARCH equation for the Sensitive index obey the restrictions inherent in the model in terms of their signs as well as magnitude. The first panel shows the spillover explained through the use of the GARCH models where the residuals have been extracted after estimating the GARCH for each of the markets and the same was used as the shock (as a proxy for volatility) spilling over to other market. With reference to equations 1 to 5 , the coefficient ' $y$ ' represents the volatility spillover parameter. It may be pointed out here that in the case of the GARCH model, squared residuals were used instead of residuals on their level in order to ensure positivity in variance or volatility. This is, however, not the case for the EGARCH model as the definition of the model ensures variance turning to be positive. The results in Table 12 show that the volatility spillover parameter is significant in the case of both the markets (in between BSE 30 Ret and HSI Return) and for both the models. This led us to conclude that there exists bi-directional volatility spillover between the Indian Stock Market and the Hong Kong Stock Market. Test for autocorrelation as well as the ARCH effect in the residuals and squared residuals also validate the estimation of the models. The results show non-existence of the same among the residuals after estimating the GARCH and EGARCH models.

The second approach that we adopted to test for volatility spillover was through the cointegration analysis. Here, first we extracted the volatility series from each of the models for each market. Then an attempt was made to explore the co-integration relationship, if any, between the volatility series of the Indian stock market and the Hong Kong stock market. To examine the co-integration relationship we used the Johansen Maximum Likelihood (1988) procedure. The results of co-integration relationship between the volatility series of Sensex (BSE 30 Ret) and Hang Seng Index return (HSI Ret) through the GARCH and the EGARCH models are provided in Tables 13 and 14 respectively.

In Table 13, the co-integration result of the volatility series of return of Sensex and HSI is presented. The test of trace statistics shows that the null hypothesis of variables is not co-integrated $(r=0)$ against the alternative hypothesis of one or more co-integrating vectors $(r>0)$. Since 145.10 exceed the 5\% and $1 \%$ critical value of ltrace statistic (in the first panel of Table 6.24), it is possible to reject the null hypothesis of no co-integrating vectors and accept the alternative of one or more cointegrating vectors. Next, we used the ltrace (1) statistic to test the null of $r £ 1$ against the alternative of two co-integrating vectors. Since the ltrace (1) statistic of 36.99 is greater at both the $1 \%$ and $5 \%$ critical value of 6.65 and 3.76 respectively, we concluded that there are two cointegrating vectors.

If we use the lmax statistic, the null hypothesis of the no co-integrating vectors $(r=0)$ against the specific alternative $r=1$ is already rejected. The calculated value $\operatorname{lmax}(0,1)=108.11$ exceeded the $5 \%$ and $1 \%$ critical values. Hence, the null hypothesis was rejected. To test $r=1$ against the alternative hypothesis of $r=2$, the calculated value of $\operatorname{lmax}(1,2)$ was 36.99 which exceeded the critical values at the $5 \%$ and $1 \%$ significance levels are $3.76 \%$ and $6.65 \%$ respectively. Thus, it is concluded that there are two co-integrating vectors. 
The co-integrating relationship between the volatility series of the return of Sensex (BSE 30) Ret and HSI Ret through EGARCH model are presented in Table 14. The test of trace statistics shows that the null hypothesis of variables are not co-integrated $(r=0)$ against the alternative hypothesis of one or more than one co-integrating vector $(r>0)$ is rejected. The ltrace (1) statistic to test the null of $\mathrm{r} £ 1$ against the alternative of more than one $(r>1)$ co-integrating vectors shows that there are two co-integrating vectors. From lmax statistics, it is shown that there is the presence of two co-integrating vectors as the null hypothesis $r=1$ is rejected. From these observations, it is concluded that there are two co-integrating vectors.

Hence, from the GARCH and the EGARCH models, it is concluded that there exists a longrun relationship between the volatility of the return series of Sensex (BSE 30) and HSI and both the markets move in tandem with each other.

In a similar interpretation of volatility spillovers between the Indian stock market and the regional stock markets during all the three phases, it can be safely concluded that there exists a bidirectional volatility spillover between the Indian stock market and the Hong Kong stock market, the Indian stock market and the Malaysia stock market, the Indian stock market and the Japanese stock market, and the Indian stock market and the Singapore stock market.

Finally, to examine whether the integrated markets are efficient, we conducted the efficient market hypothesis test of the regional stock markets all the three phases. The empirical results of the Lo and Mackinlay and Chow and Denning (1993) variance ratio tests are reported in Table 15. For comparison purposes, the individual variance ratios (Lo and MackKinlay variance ratios) and the corresponding homoscadasticity and hetroscadasticity robust test statistics for various investment horizons like 2, 4, 8, and 16 are presented in the table. From this result, we concluded that all the stock market indices reject the random walk hypothesis. This result has also confirms that all the regional stock market indices, including the Indian stock market are not following the weak form of efficiency. Hence, we may conclude over here that the integration of the financial market does not necessarily lead to a weak form of market efficiency.

\section{Conclusion}

The pairwise Granger's causality result surmised that there exists consistent short-term causality between the regional stock markets during the global financial crisis and the postglobal financial crisis period in comparison to the entire period of the study. This may be due to the fact that the global financial crisis integrates the regional markets in Asia more strongly in the short term from 2007 onwards. Surprisingly, the co-integration result confirmed that no longrun equilibrium relationship exists between the Indian and the regional stock markets during any of the study periods. While examining the volatility spillovers between the Indian stock market and the regional stock markets, the study found bidirectional volatility spillovers between the Indian stock market and the Hong Kong stock market, Indian stock market and the Malaysian stock market, the Indian stock market and the Japanese stock market, and the Indian stock market and the Singapore stock market. From the multiple variance ratio tests, we found that neither the Indian stock markets nor any of the regional stock market follows the weak form of efficiency.

From a policy perspective, co-integrated stock markets would contribute to financial stability since they cannot deviate too far from the long-run equilibrium path. From the standpoint of their portfolio diversification objectives, investors cannot benefit from arbitrage activities in the long- run. However, in the short run, markets would continue to be influenced by the portfolio diversification objectives of foreign investors. The lack of evidence of integration of the Indian stock markets with the regional stock markets in terms of local currency gives rise to a concern that India's stock market integration may not be complete. 


\section{References}

Abdalla, I. S. A., \& Murinde, V. (1997). Exchange rate and stock price interactions in emerging markets: Evidence on India, Korea, Pakistan and the Philippines, Applied Financial economics, 7, 25-35.

Adler \& Dumas, B. (1983). International portfolio choice and corporation finance: a synthesis. Journal of Finance, 38, 925984.

Aggarwala, R. (1981). Exchange rates and stock prices: a study of the us capital markets under floating exchange rates, Akron Business and Economic Review, 12, 7-12.

Aghion, P., \& P, Howitt. (1992). A model of growth through creative destruction., Econometrica, 60, 323-351.

Ahmet \& Hasan. (2011). Testing the weak form efficiency of the turkish stock market. African Journal of Business Management, 5 (34), 13044-56?. http:// www.academicjournals.org/AJBM.

Ajayi, A. R., \& Mougoue, M. (1996). On the dynamic relation between stock prices and exchange rates. The Journal of Financial Research, XIX, 2, summer, 193-207.

Al-Jafari, Mohamed K. (2011). Testing the weakform efficiency of Bahrain securities market. International Research Journal of Finance and Economics, ISSN, 145087, 72, 14-24. http://www.eurojournals. com/finance.htm

Awokuse, T.O. (2007). Causality between exports, imports, and economic growth: Evidence from transition economies. Economics letters, 94, 389-395.

Ben S. Bernanke. (2009). Asia and the global financial crisis: A speech at the Federal Reserve Bank of San Francisco's Conference on Asia and the global financial crisis, Santa Barbara, California, October 19, 2009., Speech 481, Board of Governors of the Federal Reserve System (U.S.).

Bhatt, Vipul., \& Virmani, Arvind. (2005). Global integration of India's money market: Interest rate parity in India, Working Paper, 164, Indian Council for Research on International Economic Relations, www.icrier.org.

Bhoi, B.K., \& Dhall, S.C.. (1998). Integration of financial markets in India: an Empirical Evaluation. RBI Occasional Papers, 19, 4, 345-80.

Bhoi, J. R., \& Dhal, S. (2008). Integration of India's stock market with global and major regional markets. Bank for International Settlements (BIS) Papers. 42, ISBN: 9291317780, 202-236, https:// www.bis.org/publ/bppdf/bispap42h.pdf

Bhole, L.M. (1999). Financial institutions and markets, Bombay. Himalaya Publishing house.

Bank for International Settlements. (2006). Regional financial integration in emerging markets: Trends and policy challenges. Unpublished Paper, quoted in RBI: Currency and Finance, 2007.

Chow, K.V., \& Denning, K.C. (1993). A simple multiple variance ratio test. Journal of Econometrics, 58, 385-401.

Dominguez \& Tesar. (2001). A reexamination of exchange-rate exposure. The American Economic Review, 91(2), 396-399.

Dornbusch, R., \& Fischer, S. (1980). Exchange rates and the current account. AER, 70 (5), 960-71.

Dunning, J. H. (1993). Multinational Enterprises and the Global Economy. Addison Wesley Publishing Company.

Errunza, Vihang R. (2001). Foreign portfolio equity investments, financial liberalization, and economic development. Review of International Economics, 9, 703-26.

Fama, E. F. (1965). The behavior of stockmarket prices. Journal of Business, 38(1), 34-105.

Fama, E. F \& Blume, M. E. (1966). Filter rules and stock-market trading. The Journal of Business, 39(S1), 226-41.

Fama, E. F., Fisher, L., Jensen, M. C., \& Roll, R. (1969). The adjustment of stock prices to new information. International Economic Review, 10(1), 1-21.

Fama, E. (1970). Efficient Capital Markets: A Review of Theory and Empirical Work. Journal of Finance, 25, 383-417.

Fama, E., \& French, K. (1988). Permanent and 
Temporary Components of Stock Prices. Journal of Political Economy, 96, 24673.

Lo, A., \& MacKinlay, A.C. (1988). Stock market prices do not follow random walks: Evidence from a simple specification test. Review of Financial Studies, 1(1), 41-66.

Markusen, J. R., \& Maskus, K. E. (2002). Discriminating among alternative theories of the multinational enterprise. Review of International Economics, 10(4), 694-707.

McKinnon, R.I. (1973). Money and capital in economic development. Washington D.C.: The Brookings Institution

Mehra, Rajnish., \& Prescott, E.C. (1985). The Equity Premium A Puzzle. Journal of Monetary Economics, 145-161.

Mishra, A.K. (2004). Stock market and foreign exchange market in India: Are theyRelated? South Asia Economic Journal, 5(2), 209-232.

Mishra, A.K., \& Paul, Thomas. (2010). An empirical study of the integration and efficiency of stock and foreign exchange markets in India. EUL Journal of Social Sciences, 1(1), 108-140.

Mobarek, Asma., \& Keasey, Keavin. (2011). Weak- form market efficiency of an emerging market: Evidence from Dhaka stock market of Bangladesh. Journal of Emerging Market Finance, 1-30.

Mohan, Rakesh. (2005). Globalization, financial markets and the operation of monetary policy in India. BIS Papers, 23.

Petrakos, G., Arvanitidis, P., \& Pavleas, S. (2007). Determinants of economic growth: The experts' view. Discussion
Paper Series,University of Thessaly, 13(10), 245-76.

Rangarajan, C. (1994). Indian financial system:

The emerging horizon. RBI Bulletin, June, 747-58.

RBI. (2000). Financial market integration. Report on Currency and Finance, 26.

Reddy, Y.V. (1999). Financial sector reforms: Review and prospects. RBI Bulletin, January, 33-43.

Reddy, Y. V. (2002). Dimensions of Financial development, market reforms and integration: The Indian experience. In Macroeconomics and monetary policy: Issues for a Reforming Economy. M. S. Ahluwalia, Bimal Jalan \& S. S. Tarapore (Eds.). New Delhi: Oxford University Press.

Reddy, Y.V. (2003). Towards globalization in the financial sector in India. World Bank International Monetary Fund.

Redel. (1997). Capital market integration in developing asia. Blackwell Publishers Ltd.

Reserve Bank of India. (1985). Report of the committee to Review the working of the monetary system (Chairman, S. Chakravarty).

Reserve Bank of India. (1991). Report of the committee on financial system, (Chairman, M. Narasimhan).

Toda, H.Y. \&., Phillips, P.C.B. (1993). Vector autoregression and causality. Econometrica, 61, 1367-1393

Toda, H.Y. \&., Yamamoto. (1995). Statistical inference in vector autoregressions with possibly integrated processes. Journal of Econometrics, 66, 225-250. 
Appendix

Table 4 (A)

\begin{tabular}{ccccccc}
\hline \multicolumn{7}{c}{$\begin{array}{c}\text { Lag oder selection criteria: } \\
\text { Phase 1: Whole Sample }\end{array}$} \\
\hline Lag & LogL & LR & FPE & AIC & SC & HQ \\
0 & 86419.05 & NA & $1.33 \mathrm{E}-28$ & -44.32524 & -44.31398 & -44.32124 \\
1 & 86714.35 & 589.378 & $1.17 \mathrm{E}-28$ & -44.45158 & $-44.36154^{*}$ & -44.41962 \\
2 & 86832.17 & 234.731 & $1.13 \mathrm{E}-28$ & -44.48688 & -44.31807 & $-44.42696^{*}$ \\
3 & 86917.63 & 169.974 & $1.11 \mathrm{E}-28$ & -44.50558 & -44.258 & -44.41771 \\
4 & 86973.23 & 110.3555 & $1.10 \mathrm{E}-28$ & -44.50896 & -44.1826 & -44.39313 \\
5 & 87035.39 & 123.1896 & $1.10 \mathrm{E}-28 *$ & $-44.51572^{*}$ & -44.11058 & -44.37192 \\
6 & 87068.82 & 66.12197 & $1.10 \mathrm{E}-28$ & -44.50773 & -44.02381 & -44.33597 \\
7 & 87112.73 & 86.68907 & $1.11 \mathrm{E}-28$ & -44.50512 & -43.94242 & -44.3054 \\
8 & 87159.88 & 92.91393 & $1.11 \mathrm{E}-28$ & -44.50417 & -43.86269 & -44.27649 \\
\hline
\end{tabular}

Table 4 (B)

\begin{tabular}{ccccccc}
\hline \multicolumn{7}{c}{ Phase V: 2007-2008: Global financial crisis } \\
\hline Lag & LogL & LR & FPE & AIC & SC & HQ \\
0 & 9775.505 & NA & $3.93 \mathrm{E}-29$ & -45.54082 & $-45.47455^{*}$ & $-45.51465^{*}$ \\
1 & 9860.815 & 167.4382 & $3.32 \mathrm{E}-29$ & -45.7101 & -45.17993 & -45.50073 \\
2 & 9911.145 & 97.13957 & $3.30 \mathrm{E}-29 *$ & $-45.71629^{*}$ & -44.72223 & -45.32373 \\
3 & 9948.4 & 70.68831 & $3.49 \mathrm{E}-29$ & -45.66154 & -44.20358 & -45.08578 \\
4 & 9975.75 & 51.00373 & $3.86 \mathrm{E}-29$ & -45.56061 & -43.63875 & -44.80165 \\
5 & 10021.56 & 83.92835 & $3.92 \mathrm{E}-29$ & -45.54573 & -43.15998 & -44.60358 \\
6 & 10073.18 & $92.89655^{*}$ & $3.88 \mathrm{E}-29$ & -45.55795 & -42.70831 & -44.43261 \\
7 & 10105.44 & 57.00529 & $4.21 \mathrm{E}-29$ & -45.47993 & -42.16638 & -44.17138 \\
$\mathbf{8}$ & 10138.64 & 57.56336 & $4.55 \mathrm{E}-29$ & -45.40623 & -41.62879 & -43.91449 \\
\hline
\end{tabular}

Table $4(\mathrm{C})$

\begin{tabular}{clccccc}
\hline \multicolumn{7}{c}{ Phase VI: 2009-2012: Post Global Financial Crisis } \\
\hline Lag & LogL & \multicolumn{1}{c}{ LR } & FPE & AIC & SC & HQ \\
$\mathbf{0}$ & 17731.01 & NA & $6.94 \mathrm{E}-31$ & -49.57765 & $-49.53289^{*}$ & -49.56036 \\
$\mathbf{1}$ & 17863.57 & 262.158 & $5.49 \mathrm{E}-31$ & -49.81139 & -49.45328 & $-49.67310^{*}$ \\
$\mathbf{2}$ & 17917.18 & 104.9716 & $5.42 \mathrm{E}-31$ & -49.82429 & -49.15283 & -49.56499 \\
$\mathbf{3}$ & 17957.29 & 77.7382 & $5.56 \mathrm{E}-31$ & -49.7994 & -48.8146 & -49.41909 \\
$\mathbf{4}$ & 18008.88 & 99.00987 & $5.52 \mathrm{E}-31$ & -49.80667 & -48.50852 & -49.30535 \\
$\mathbf{5}$ & 18050.86 & 79.72692 & $5.63 \mathrm{E}-31$ & -49.78702 & -48.17553 & -49.1647 \\
$\mathbf{6}$ & 18094.22 & 81.50809 & $5.72 \mathrm{E}-31$ & -49.77125 & -47.84642 & -49.02792 \\
$\mathbf{7}$ & 18167.75 & $136.7811^{*}$ & $5.35 \mathrm{E}-31 *$ & $-49.83987 *$ & -47.60169 & -48.97553 \\
$\mathbf{8}$ & 18196.44 & 52.79669 & $5.67 \mathrm{E}-31$ & -49.78305 & -47.23152 & -48.7977 \\
\hline
\end{tabular}


Table 5

VAR Granger Causality/ Block Exogeneity Wald Test Results at the Level of Stock Returns: Whole sample

\begin{tabular}{|c|c|c|c|c|}
\hline Dependent Variables & Excluded & Chi-square statistics & DF & P-value \\
\hline \multirow{7}{*}{ BSE30RET } & BSE100RET & 69.83418 & 5 & 0.00 \\
\hline & NIFTYRET & 129.8813 & 5 & 0.00 \\
\hline & HSIRET** & 1.653563 & 5 & 0.89 \\
\hline & KLSERET & 54.12214 & 5 & 0.00 \\
\hline & NIKKEI225RET & 46.51558 & 5 & 0.00 \\
\hline & STIRET & 9.777059 & 5 & 0.08 \\
\hline & All & 176.1903 & 30 & 0.00 \\
\hline \multirow{7}{*}{ BSE100RET } & BSE30RET & 82.8196 & 5 & 0.00 \\
\hline & NIFTYRET & 68.74218 & 5 & 0.00 \\
\hline & HSIRET* & 1.60888 & 5 & 0.90 \\
\hline & KLSERET & 27.89535 & 5 & 0.00 \\
\hline & NIKKEI225RET & 26.93973 & 5 & 0.00 \\
\hline & STIRET & 8.419992 & 5 & 0.13 \\
\hline & All & 108.2669 & 30 & 0.00 \\
\hline \multirow{7}{*}{ NIFTYRET } & BSE30RET & 83.16408 & 5 & 0.00 \\
\hline & BSE100RET & 23.14387 & 5 & 0.00 \\
\hline & HSIRET* & 0.985075 & 5 & 0.96 \\
\hline & KLSERET & 19.88543 & 5 & 0.00 \\
\hline & NIKKEI225RET & 21.70799 & 5 & 0.00 \\
\hline & STIRET & 8.001359 & 5 & 0.16 \\
\hline & All & 110.4825 & 30 & 0.00 \\
\hline \multirow{7}{*}{ HSIRET* } & BSE30RET & 8.452025 & 5 & 0.13 \\
\hline & BSE100RET & 3.5639 & 5 & 0.61 \\
\hline & NIFTYRET & 7.066354 & 5 & 0.22 \\
\hline & KLSERET & 5.843618 & 5 & 0.32 \\
\hline & NIKKEI225RET & 4.774707 & 5 & 0.44 \\
\hline & STIRET & 20.61178 & 5 & 0.00 \\
\hline & All & 56.46727 & 30 & 0.00 \\
\hline \multirow{7}{*}{ KLSERET } & BSE30RET & 41.18925 & 5 & 0.00 \\
\hline & BSE100RET & 8.133887 & 5 & 0.15 \\
\hline & NIFTYRET & 49.8485 & 5 & 0.00 \\
\hline & HSIRET* & 13.57284 & 5 & 0.02 \\
\hline & NIKKEI225RET & 30.95355 & 5 & 0.00 \\
\hline & STIRET & 7.190702 & 5 & 0.21 \\
\hline & All & 98.8017 & 30 & 0.00 \\
\hline
\end{tabular}

(continued) 
Malaysian Management Journal Vol. 20, December 2016 13-39

\begin{tabular}{llccc}
\hline Dependent Variables & \multicolumn{1}{c}{ Excluded } & Chi-square statistics & DF & P-value \\
\hline & BSE30RET & 16.89614 & 5 & 0.00 \\
BSE100RET & 3.044658 & 5 & 0.69 \\
NIFTYRET & 22.75428 & 5 & 0.00 \\
NIKKEI225RET & HSIRET* & 3.876285 & 5 & 0.57 \\
KLSERET & 7.425942 & 5 & 0.19 \\
STIRET & 14.83655 & 5 & 0.01 \\
All & 74.49403 & 30 & 0.00 \\
BSE30RET & 6.366303 & 5 & 0.27 \\
BSE100RET & 6.421214 & 5 & 0.27 \\
NIFTYRET & 4.552266 & 5 & 0.04 \\
HSIRET & 11.38233 & 5 & 0.36 \\
KLSERET & 5.516356 & 5 & 0.11 \\
NIKKEI225RET & 8.932217 & 5 & 0.01 \\
\hline
\end{tabular}

Table 6

VAR Granger Causality/ Block Exogeneity Wald Test Results at the Level of Stock Returns: Global Financial Crisis

\begin{tabular}{|c|c|c|c|c|}
\hline Dependent variables & Excluded & Chi-square statistics & $\mathrm{DF}$ & P-value \\
\hline \multirow{7}{*}{ BSE30RET } & BSE100RET & 24.7888 & 2 & 0.00 \\
\hline & NIFTYRET & 0.188236 & 2 & 0.91 \\
\hline & HSIRET* & 4.777667 & 2 & 0.09 \\
\hline & KLSERET & 11.11501 & 2 & 0.00 \\
\hline & NIKKEI225RET & 11.92286 & 2 & 0.00 \\
\hline & STIRET & 6.115619 & 2 & 0.05 \\
\hline & All & 63.63946 & 12 & 0.00 \\
\hline \multirow{7}{*}{ BSE100RET } & BSE30RET & 21.1822 & 2 & 0.00 \\
\hline & NIFTYRET & 0.225879 & 2 & 0.89 \\
\hline & HSIRET* & 4.238139 & 2 & 0.12 \\
\hline & KLSERET & 10.71501 & 2 & 0.00 \\
\hline & NIKKEI225RET & 11.04981 & 2 & 0.00 \\
\hline & STIRET & 5.764765 & 2 & 0.06 \\
\hline & All & 48.42248 & 12 & 0.00 \\
\hline \multirow{7}{*}{ NIFTYRET } & BSE30RET & 24.52265 & 2 & 0.00 \\
\hline & BSE100RET & 16.82256 & 2 & 0.00 \\
\hline & HSIRET* & 4.710219 & 2 & 0.09 \\
\hline & KLSERET & 10.60463 & 2 & 0.01 \\
\hline & NIKKEI225RET & 10.8923 & 2 & 0.00 \\
\hline & STIRET & 6.311061 & 2 & 0.04 \\
\hline & All & 52.35294 & 12 & 0.00 \\
\hline
\end{tabular}




\begin{tabular}{|c|c|c|c|c|}
\hline Dependent variables & Excluded & Chi-square statistics & DF & P-value \\
\hline \multirow{7}{*}{ HSIRET** } & BSE30RET & 13.90294 & 2 & 0.00 \\
\hline & BSE100RET & 11.40286 & 2 & 0.00 \\
\hline & NIFTYRET & 0.061638 & 2 & 0.97 \\
\hline & KLSERET & 13.21825 & 2 & 0.00 \\
\hline & NIKKEI225RET & 0.290178 & 2 & 0.86 \\
\hline & STIRET & 10.74281 & 2 & 0.00 \\
\hline & All & 46.89313 & 12 & 0.00 \\
\hline \multirow{7}{*}{ KLSERET } & BSE30RET & 4.222822 & 2 & 0.12 \\
\hline & BSE100RET & 1.536123 & 2 & 0.46 \\
\hline & NIFTYRET & 0.764292 & 2 & 0.68 \\
\hline & HSIRET** & 0.064364 & 2 & 0.97 \\
\hline & NIKKEI225RET & 6.402168 & 2 & 0.04 \\
\hline & STIRET & 6.42092 & 2 & 0.04 \\
\hline & All & 26.9347 & 12 & 0.01 \\
\hline \multirow{7}{*}{ NIKKEI225RET } & BSE30RET & 37.78466 & 2 & 0.00 \\
\hline & BSE100RET & 22.38511 & 2 & 0.00 \\
\hline & NIFTYRET & 1.805944 & 2 & 0.41 \\
\hline & HSIRET** & 0.358798 & 2 & 0.84 \\
\hline & KLSERET & 7.299312 & 2 & 0.03 \\
\hline & STIRET & 14.17515 & 2 & 0.00 \\
\hline & All & 83.05482 & 12 & 0.00 \\
\hline \multirow{7}{*}{ STIRET } & BSE30RET & 18.39083 & 2 & 0.00 \\
\hline & BSE100RET & 13.38063 & 2 & 0.00 \\
\hline & NIFTYRET & 3.147038 & 2 & 0.21 \\
\hline & HSIRET* & 1.556601 & 2 & 0.46 \\
\hline & KLSERET & 13.71607 & 2 & 0.00 \\
\hline & NIKKEI225RET & 2.794638 & 2 & 0.25 \\
\hline & All & 46.05447 & 12 & 0.00 \\
\hline
\end{tabular}

Table 7

VAR Granger Causality/ Block Exogeneity Wald Test Results at the Level of Stock Returns: Post Global Financial Crisis

\begin{tabular}{llrrr}
\hline Dependent variables & \multicolumn{1}{c}{ Excluded } & Chi-square statistics & DF & P-value \\
\hline & BSE100RET & 6.011777 & 7 & 0.54 \\
& NIFTYRET & 18.69181 & 7 & 0.01 \\
& HSIRET* & 17.98718 & 7 & 0.01 \\
BSE30RET & KLSERET & 18.09185 & 7 & 0.01 \\
& NIKKEI225RET & 23.30731 & 7 & 0.00 \\
& STIRET & 42.15388 & 7 & 0.00 \\
& All & 120.4568 & 42 & 0.00 \\
\hline & & & & (continued)
\end{tabular}




\begin{tabular}{|c|c|c|c|c|}
\hline Dependent variables & Excluded & Chi-square statistics & $\mathrm{DF}$ & P-value \\
\hline \multirow{7}{*}{ BSE100RET } & BSE30RET & 37.05285 & 7 & 0.00 \\
\hline & NIFTYRET & 19.03846 & 7 & 0.01 \\
\hline & HSIRET* & 16.62394 & 7 & 0.02 \\
\hline & KLSERET & 18.64946 & 7 & 0.01 \\
\hline & NIKKEI225RET & 21.3107 & 7 & 0.00 \\
\hline & STIRET & 39.36034 & 7 & 0.00 \\
\hline & All & 113.2809 & 42 & 0.00 \\
\hline \multirow{7}{*}{ NIFTYRET } & BSE30RET & 37.47428 & 7 & 0.00 \\
\hline & BSE100RET & 4.341742 & 7 & 0.74 \\
\hline & HSIRET* & 17.14513 & 7 & 0.02 \\
\hline & KLSERET & 17.41654 & 7 & 0.01 \\
\hline & NIKKEI225RET & 21.99416 & 7 & 0.00 \\
\hline & STIRET & 39.48235 & 7 & 0.00 \\
\hline & All & 114.4309 & 42 & 0.00 \\
\hline \multirow{7}{*}{ HSIRET* } & BSE30RET & 6.513559 & 7 & 0.48 \\
\hline & BSE100RET & 12.42421 & 7 & 0.09 \\
\hline & NIFTYRET & 3.956537 & 7 & 0.78 \\
\hline & KLSERET & 14.72031 & 7 & 0.04 \\
\hline & NIKKEI225RET & 22.20577 & 7 & 0.00 \\
\hline & STIRET & 39.48585 & 7 & 0.00 \\
\hline & All & 102.0663 & 42 & 0.00 \\
\hline \multirow{7}{*}{ KLSERET } & BSE30RET & 4.033252 & 7 & 0.78 \\
\hline & BSE100RET & 3.00926 & 7 & 0.88 \\
\hline & NIFTYRET & 1.985149 & 7 & 0.96 \\
\hline & HSIRET* & 12.25388 & 7 & 0.09 \\
\hline & NIKKEI225RET & 9.516664 & 7 & 0.22 \\
\hline & STIRET & 10.27857 & 7 & 0.17 \\
\hline & All & 85.43187 & 42 & 0.00 \\
\hline \multirow{7}{*}{ NIKKEI225RET } & BSE30RET & 4.801765 & 7 & 0.68 \\
\hline & BSE100RET & 8.154508 & 7 & 0.32 \\
\hline & NIFTYRET & 7.813232 & 7 & 0.35 \\
\hline & HSIRET* & 6.972225 & 7 & 0.43 \\
\hline & KLSERET & 10.79695 & 7 & 0.15 \\
\hline & STIRET & 13.69886 & 7 & 0.06 \\
\hline & All & 59.13775 & 42 & 0.04 \\
\hline \multirow{7}{*}{ STIRET } & BSE30RET & 10.84176 & 7 & 0.15 \\
\hline & BSE100RET & 13.24819 & 7 & 0.07 \\
\hline & NIFTYRET & 10.15683 & 7 & 0.18 \\
\hline & HSIRET* & 30.40593 & 7 & 0.00 \\
\hline & KLSERET & 31.1902 & 7 & 0.00 \\
\hline & NIKKEI225RET & 19.45679 & 7 & 0.01 \\
\hline & All & 107.6928 & 42 & 0.00 \\
\hline
\end{tabular}


Table 8

Co-integration: Whole Sample

\begin{tabular}{lrcrc}
\hline \multicolumn{1}{c}{ Null hypothesis } & \multicolumn{2}{c}{ Alternative hypothesis } & Whole sample & \multicolumn{2}{c}{ CRITICAL VALUES } \\
\hline \multicolumn{1}{c}{$\lambda$ TRACE Tests } & \multicolumn{1}{c}{$\lambda$ TRACE Tests } & $\lambda$ TRACE Values & $5 \%$ & $1 \%$ \\
\hline $\mathrm{r}=0$ & $\mathrm{r}>0$ & 130.77 & 124.24 & 133.57 \\
$\mathrm{r} \leq 1$ & $\mathrm{r}>1$ & 84.42 & 94.15 & 103.18 \\
$\mathrm{r} \leq 2$ & $\mathrm{r}>2$ & - & $5 \%$ & $1 \%$ \\
$\quad \lambda$ MAX Tests & \multicolumn{2}{c}{$\lambda$ MAX Tests } & $\lambda$ MAX Values & 51.57 \\
$\mathrm{r}=0$ & $\mathrm{r}=1$ & 46.34 & 45.28 & 45.1 \\
$\mathrm{r}=1$ & $\mathrm{r}=2$ & 31.61 & 39.37 & - \\
$\mathrm{r}=2$ & $\mathrm{r}=3$ & - & & - \\
\hline
\end{tabular}

Table 9

Co-integration: Global Financial Crisis $\leq$

\begin{tabular}{|c|c|c|c|c|}
\hline Null hypothesis & Alternative hypothesis & Whole sample & \multicolumn{2}{|c|}{ CRITICAL VALUES } \\
\hline$\lambda$ TRACE Tests & $\lambda$ TRACE Tests & 1 TRACE Values & $5 \%$ & $1 \%$ \\
\hline $\mathrm{r}=0$ & $r>0$ & 125.54 & 124.24 & 133.57 \\
\hline$r \leq 1$ & $r>1$ & 87.27 & 94.15 & 103.18 \\
\hline$r \leq 2$ & $\mathrm{r}>2$ & - & & \\
\hline$\lambda$ MAX Tests & $\lambda$ MAX Tests & $\lambda$ MAX Values & $5 \%$ & $1 \%$ \\
\hline $\mathrm{r}=0$ & $\mathrm{r}=1$ & 38.26 & 45.28 & 51.57 \\
\hline$r=1$ & $r=2$ & 33.06 & 39.37 & 45.1 \\
\hline$r=2$ & $r=3$ & - & - & - \\
\hline
\end{tabular}

Table 10

Co-integration: Post Global Financial Crisis

\begin{tabular}{|c|c|c|c|c|}
\hline Null hypothesis & Alternative hypothesis & Whole sample & \multicolumn{2}{|c|}{ CRITICAL VALUES } \\
\hline$\lambda$ TRACE Tests & $\lambda$ TRACE Tests & $\lambda$ TRACE Values & $5 \%$ & $1 \%$ \\
\hline $\mathrm{r}=0$ & $r>0$ & 130.35 & 124.24 & 133.57 \\
\hline$r \leq 1$ & $r>1$ & 83.44 & 94.15 & 103.18 \\
\hline$r \leq 2$ & $r>2$ & - & - & - \\
\hline$\lambda$ MAX Tests & $\lambda$ MAX Tests & $\lambda$ MAX Values & $5 \%$ & $1 \%$ \\
\hline $\mathrm{r}=0$ & $\mathrm{r}=1$ & 46.91 & 45.28 & 51.57 \\
\hline$r=1$ & $r=2$ & 28.39 & 39.37 & 45.1 \\
\hline$r=2$ & $r=3$ & - & - & - \\
\hline
\end{tabular}

Volatility Spillover: Regional Stock Markets 
Table 11

ARMA $(1,1)$ Model Fitted to the Data

\begin{tabular}{|c|c|c|c|c|c|c|}
\hline Variable & Constant & $\mathrm{AR}(1)$ & $\mathrm{MA}(1)$ & $\mathrm{Q}(8)^{5}$ & $\mathrm{Q}^{2}(8)^{6}$ & $\mathrm{LM}^{7}$ \\
\hline BSE 30 RET & $\begin{array}{c}0.000 \\
(0.17)\end{array}$ & $\begin{array}{c}0.030 \\
(1.91)\end{array}$ & - & $\begin{array}{l}16.502 \\
(0.021)\end{array}$ & $\begin{array}{r}359.64 \\
(0.00)\end{array}$ & $\begin{array}{c}105.703 \\
(0.00)\end{array}$ \\
\hline BSE 100 RET & $\begin{array}{c}0.000 \\
(0.16)\end{array}$ & $\begin{array}{c}0.054 \\
(0.00)\end{array}$ & - & $\begin{array}{c}14.962 \\
(0.036)\end{array}$ & $\begin{array}{r}291.48 \\
(0.00)\end{array}$ & $\begin{array}{c}115.223 \\
(0.00)\end{array}$ \\
\hline NIFTY RET & $\begin{array}{c}0.000 \\
(0.17)\end{array}$ & $\begin{array}{c}0.029 \\
(0.06)\end{array}$ & - & $\begin{array}{l}13.900 \\
(0.05)\end{array}$ & $\begin{array}{r}232.99 \\
(0.00)\end{array}$ & $\begin{array}{c}84.314 \\
(0.00)\end{array}$ \\
\hline HSI RET & $\begin{array}{c}0.00 \\
(0.63)\end{array}$ & $\begin{array}{l}-0.720 \\
(0.00)\end{array}$ & $\begin{array}{c}0.743 \\
(0.00)\end{array}$ & $\begin{array}{l}12.110 \\
(0.06)\end{array}$ & $\begin{array}{r}370.45 \\
(0.00)\end{array}$ & $\begin{array}{c}46.090 \\
(0.00)\end{array}$ \\
\hline KLSE RET* & $\begin{array}{c}0.000 \\
(0.82)\end{array}$ & $\begin{array}{l}-0.044 \\
(0.00)\end{array}$ & - & $\begin{array}{l}72.991 \\
(0.00)\end{array}$ & $\begin{array}{r}1228.3 \\
(0.00)\end{array}$ & $\begin{array}{r}769.75 \\
(0.00)\end{array}$ \\
\hline NIKKEI225 RET & $\begin{array}{c}0.000 \\
(0.07)\end{array}$ & $\begin{array}{c}0.918 \\
(0.00)\end{array}$ & $\begin{array}{l}-0.925 \\
(0.00)\end{array}$ & $\begin{array}{l}17.157 \\
(0.01)\end{array}$ & $\begin{array}{r}1553.8 \\
(0.00)\end{array}$ & $\begin{array}{r}237.70 \\
(0.00)\end{array}$ \\
\hline STI RET & $\begin{array}{c}0.000 \\
(0.83)\end{array}$ & $\begin{array}{c}0.067 \\
(0.00)\end{array}$ & - & $\begin{array}{l}10.913 \\
(0.14)\end{array}$ & $\begin{array}{r}232.02 \\
(0.00)\end{array}$ & $\begin{array}{l}28.93 \\
(0.00)\end{array}$ \\
\hline
\end{tabular}

Notes:

- $\quad{ }^{5}$ represent L-Jung Box Q statistics for the residuals from AR (1) model

- $\quad{ }^{6}$ represent L-Jung Box Q statistics for the squared residuals from AR (1) model.

- 7 represent LaGrange Multiplier statistics to test for the presence of ARCH

- * represents Coefficient for the AR(2) model

Table 12

Volatility Spillover: BSE 30 and HSI

\begin{tabular}{|c|c|c|c|c|}
\hline \multirow{2}{*}{ Coefficients $^{1}$} & \multicolumn{2}{|c|}{$\mathrm{AR}(1)-\mathrm{GARCH}(1,1)$} & \multicolumn{2}{|c|}{$\operatorname{AR}(1)-\operatorname{EGARCH}(1,1)$} \\
\hline & BSE 30 RET®HSI RET & HSI RET® BSE 30 RET & BSE 30 RET®HSI RET & HSI RET® BSE 30 RET \\
\hline $\mathrm{C}$ & $\begin{array}{c}0.001 \\
(0.00)\end{array}$ & $\begin{array}{c}0.000 \\
(0.00)\end{array}$ & $\begin{array}{c}0.000 \\
(0.00)\end{array}$ & $\begin{array}{c}0.000 \\
(0.36)\end{array}$ \\
\hline$\tau$ & $\begin{array}{c}0.075 \\
(0.00)\end{array}$ & $\begin{array}{l}-0.658 \\
(0.00)\end{array}$ & $\begin{array}{c}0.075 \\
(0.00)\end{array}$ & $\begin{array}{c}0.974 \\
(0.00)\end{array}$ \\
\hline$\tau_{1}$ & - & $\begin{array}{c}0.693 \\
(0.00)\end{array}$ & - & $\begin{array}{l}-0.960 \\
(0.00)\end{array}$ \\
\hline$\omega_{0}$ & $\begin{array}{c}0.000 \\
(0.00)\end{array}$ & $\begin{array}{c}0.000 \\
(0.00)\end{array}$ & $\begin{array}{l}-0.477 \\
(0.00)\end{array}$ & $\begin{array}{l}-0.206 \\
(0.00)\end{array}$ \\
\hline$\beta_{1}$ & $\begin{array}{c}0.132 \\
(0.00)\end{array}$ & $\begin{array}{c}0.078 \\
(0.00)\end{array}$ & $\begin{array}{c}0.962 \\
(0.00)\end{array}$ & $\begin{array}{c}0.986 \\
(0.00)\end{array}$ \\
\hline$\alpha_{1}$ & $\begin{array}{c}0.703 \\
(0.00)\end{array}$ & $\begin{array}{c}0.869 \\
(0.00)\end{array}$ & $\begin{array}{c}0.227 \\
(0.00)\end{array}$ & $\begin{array}{c}0.129 \\
(0.00)\end{array}$ \\
\hline$\phi$ & - & - & $\begin{array}{l}-0.044 \\
(0.00)\end{array}$ & $\begin{array}{l}-0.060 \\
(0.00)\end{array}$ \\
\hline$\psi$ & $\begin{array}{c}0.121 \\
(0.00)\end{array}$ & $\begin{array}{c}0.045 \\
(0.00)\end{array}$ & $\begin{array}{l}-3.819 \\
(0.00)\end{array}$ & $\begin{array}{l}-1.586 \\
(0.00)\end{array}$ \\
\hline $\mathrm{LM}^{2}$ & $\begin{array}{c}0.121 \\
(0.72)\end{array}$ & $\begin{array}{c}9.721 \\
(0.00)\end{array}$ & $\begin{array}{c}0.353 \\
(0.55)\end{array}$ & $\begin{array}{c}5.809 \\
(0.01)\end{array}$ \\
\hline
\end{tabular}


Table 13

Co-integration Analysis: GARCH Variance (BSE 30 RET and HSIRET)

\begin{tabular}{lcccc}
\hline \multicolumn{1}{c}{ Null hypothesis } & Alternative hypothesis & Whole sample & \multicolumn{2}{c}{ CRITICAL VALUES } \\
\hline \multicolumn{1}{c}{$\lambda$ TRACE Tests } & $\lambda$ TRACE Tests & $\lambda$ TRACE Values & $5 \%$ & $1 \%$ \\
\hline $\mathrm{r}=0$ & $\mathrm{r}>0$ & 145.10 & 15.41 & 20.04 \\
$\mathrm{r} \leq 1$ & $\mathrm{r}>1$ & 36.99 & -76 & - \\
$\mathrm{r} \leq 2$ & $\mathrm{r}>2$ & - & $5 \%$ & - \\
$\quad \lambda$ MAX Tests & $\lambda$ MAX Tests & $\lambda$ MAX Values & $1 \%$ & 18.63 \\
$\mathrm{r}=0$ & $\mathrm{r}=1$ & 108.11 & 3.76 & 6.65 \\
$\mathrm{r}=1$ & $\mathrm{r}=2$ & 36.99 & - & - \\
$\mathrm{r}=2$ & $\mathrm{r}=3$ & - & & \\
\hline
\end{tabular}

Table14

Co-integration Analysis: EGARCH Variance (BSE 30 RET and HSIRET)

\begin{tabular}{|c|c|c|c|c|}
\hline Null hypothesis & Alternative hypothesis & Whole sample & \multicolumn{2}{|c|}{ CRITICAL VALUES } \\
\hline$\lambda$ TRACE Tests & $\lambda$ TRACE Tests & $\lambda$ TRACE Values & $5 \%$ & $1 \%$ \\
\hline$r=0$ & $r>0$ & 147.84 & 15.41 & 20.04 \\
\hline$r \leq 1$ & $r>1$ & 43.79 & 3.76 & 6.65 \\
\hline$r \leq 2$ & $r>2$ & - & - & - \\
\hline 1 MAX Tests & 1 MAX Tests & 1 MAX Values & $5 \%$ & $1 \%$ \\
\hline$r=0$ & $\mathrm{r}=1$ & 104.05 & 14.07 & 18.63 \\
\hline$r=1$ & $r=2$ & 43.79 & 3.76 & 6.65 \\
\hline$r=2$ & $\mathrm{r}=3$ & - & - & - \\
\hline
\end{tabular}

Table15

Multiple Variance Ratio Test

\begin{tabular}{|c|c|c|c|c|c|c|c|}
\hline \multicolumn{8}{|c|}{ Multiple Variance Ratio Test for Daily Data of the Regional Financial Markets } \\
\hline Market & Instruments & Lags $\rightarrow$ & Lag 2 & $\operatorname{Lag} 4$ & Lag 8 & Lag 16 & Chow-Denning \\
\hline \multirow{9}{*}{$\begin{array}{l}\text { Indian Stock } \\
\text { Market }\end{array}$} & \multirow{3}{*}{ BSE30Ret } & $\operatorname{VR}(q)$ & 0.522 & 0.252 & 0.126 & 0.065 & \multirow{3}{*}{$13.455^{*}$} \\
\hline & & $\mathrm{Z}(\mathrm{q})$ & $(29.838)^{*}$ & $(24.968)^{*}$ & $(18.459)^{*}$ & $(13.266)^{*}$ & \\
\hline & & $Z *(q)$ & $(13.455)^{*}$ & $(12.774)^{*}$ & $(10.774)^{*}$ & $(8.415)^{*}$ & \\
\hline & \multirow{3}{*}{ BSE100ret } & $\operatorname{VR}(q)$ & 0.531 & 0.258 & 0.128 & 0.066 & \multirow{3}{*}{$12.041^{*}$} \\
\hline & & $\mathrm{Z}(\mathrm{q})$ & $(29.315)^{*}$ & $(24.763)^{*}$ & $(18.415)^{*}$ & $(13.253)^{*}$ & \\
\hline & & $Z^{*}(q)$ & $(12.040)^{*}$ & $(11.695)^{*}$ & $(10.131)^{*}$ & $(8.073)^{*}$ & \\
\hline & \multirow{3}{*}{ NiftyRet } & $\operatorname{VR}(q)$ & 0.524 & 0.252 & 0.126 & 0.066 & \multirow{3}{*}{$12.254 *$} \\
\hline & & $\mathrm{Z}(\mathrm{q})$ & $(29.751)^{*}$ & $(24.978)^{*}$ & $(18.454)^{*}$ & $(13.261)^{*}$ & \\
\hline & & $Z^{*}(q)$ & $(12.253)^{*}$ & $(11.804)^{*}$ & $(10.151)^{*}$ & $(8.057)^{*}$ & \\
\hline
\end{tabular}


Malaysian Management Journal Vol. 20, December 2016 13-39

\begin{tabular}{|c|c|c|c|c|c|c|c|}
\hline \multicolumn{8}{|c|}{ Multiple Variance Ratio Test for Daily Data of the Regional Financial Markets } \\
\hline Market & Instruments & Lags $\rightarrow$ & Lag 2 & Lag 4 & Lag 8 & Lag 16 & Chow-Denning \\
\hline \multirow{3}{*}{$\begin{array}{l}\text { China Stock } \\
\text { Market }\end{array}$} & \multirow{3}{*}{ HSIRet } & $\operatorname{VR}(q)$ & 0.517 & 0.257 & 0.120 & 0.060 & \multirow{3}{*}{$13.136^{*}$} \\
\hline & & $\mathrm{Z}(\mathrm{q})$ & $(30.176)^{*}$ & $(24.808)^{*}$ & $(18.589)^{*}$ & $(13.342)^{*}$ & \\
\hline & & $\mathrm{Z}^{*}(\mathrm{q})$ & $(13.136)^{*}$ & $(12.222)^{*}$ & $(10.494)^{*}$ & $(8.278)^{*}$ & \\
\hline \multirow{3}{*}{$\begin{array}{l}\text { Malaysia Stock } \\
\text { Market }\end{array}$} & \multirow{3}{*}{ KLSERet } & $\operatorname{VR}(q)$ & 0.473 & 0.268 & 0.115 & 0.058 & \multirow{3}{*}{$5.188^{*}$} \\
\hline & & $\mathrm{Z}(\mathrm{q})$ & $(32.919)^{*}$ & $(24.434)^{*}$ & $(18.694)^{*}$ & $(13.367)^{*}$ & \\
\hline & & $Z^{*}(\mathrm{q})$ & $(5.188)^{*}$ & $(4.575)^{*}$ & $(4.215)^{*}$ & $(3.646)^{*}$ & \\
\hline \multirow{3}{*}{$\begin{array}{l}\text { Japanese Stock } \\
\text { Market }\end{array}$} & \multirow{3}{*}{ NIKKEI225Ret } & $\operatorname{VR}(q)$ & 0.509 & 0.245 & 0.121 & 0.058 & \multirow{3}{*}{$15.035^{*}$} \\
\hline & & $\mathrm{Z}(\mathrm{q})$ & $(30.645)^{*}$ & $(* 25.193)$ & $(18.572)^{*}$ & $(13.364)^{*}$ & \\
\hline & & $\mathrm{Z} *(\mathrm{q})$ & $(15.035)^{*}$ & $(12.932)^{*}$ & $(10.331)^{*}$ & $(8.087)^{*}$ & \\
\hline \multirow{3}{*}{$\begin{array}{l}\text { Singapore Stock } \\
\text { Market }\end{array}$} & \multirow{3}{*}{ STIRet } & $\operatorname{VR}(q)$ & 0.546 & 0.270 & 0.129 & 0.065 & \multirow{3}{*}{$10.829 *$} \\
\hline & & $\mathrm{Z}(\mathrm{q})$ & $(28.339)^{*}$ & $(24.379)^{*}$ & $(18.387)^{*}$ & $(13.262)^{*}$ & \\
\hline & & $Z^{*}(\mathrm{q})$ & $(10.829)^{*}$ & $(10.701)^{*}$ & $(9.387)^{*}$ & $(7.565)^{*}$ & \\
\hline
\end{tabular}

